\title{
Monopoly and the Mandate of Canada Post
}

\author{
J. Gregory Sidak ${ }^{\dagger}$ and Daniel F. Spulber ${ }^{\dagger \dagger}$
}

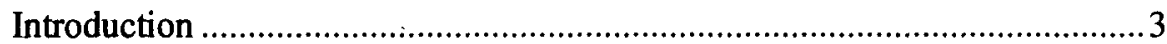

I. The Existing Regulation of Canada Post.........................................6 6

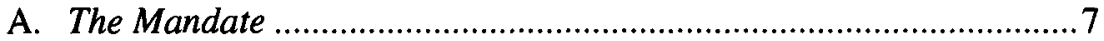

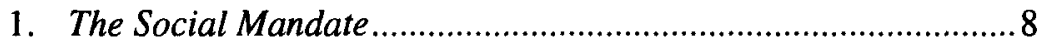

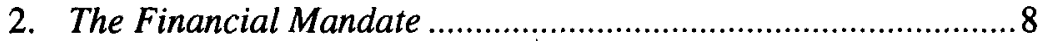

3. The Statutory Monopoly .................................................. 10

B. Competition ........................................................................... 11

1. Traditional Services and Aggressive Expansion ......................11

2. Limiting Mailbox Access ........................................................ 14

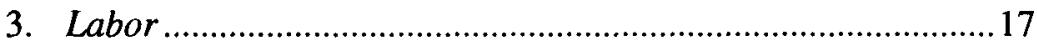

4. Pricing and Costing: Policy and Disclosure .........................20

5. The Purolator Acquisition .................................................22

6. The Bureau of Competition Policy's Analysis..........................23

C. Limited Regulatory Oversight ....................................................25

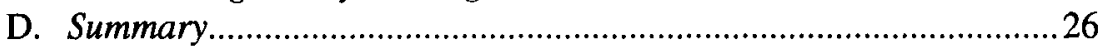

II. Technological Justifications for the Postal Monopoly ..........................227

A. The Natural Monopoly Justification for the Public Postal

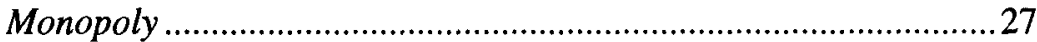

B. The Definition of Natural Monopoly .............................................28

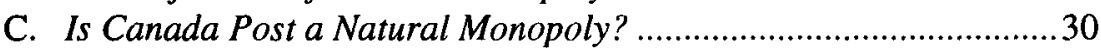

1. Contracting for Long-Distance Transportation ...................... 30

2. Regional Sortation and Transportation ................................... 31

3. Local Collection, Sortation, and Delivery............................... 31

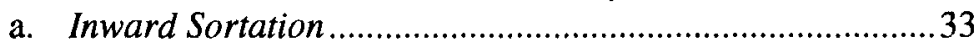

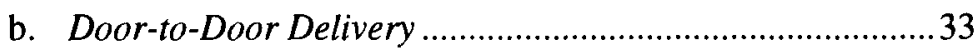

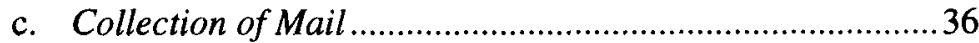

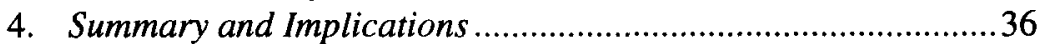

D. The Fallacy That Canada Post Must Be a Nationwide

Full-Service Carrier.................................................................... 36

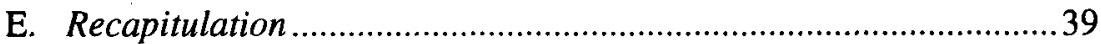

III. Public Provision of Postal Services....................................................... 40

A. The Absence of Insurmountable Technological Barriers to Entry in Postal Delivery .................................................................... 41

$\dagger$ F. K. Weyerhaeuser Fellow in Law and Economics, American Enterprise Institute for Public Policy Research; Senior Lecturer, Yale School of Management.

t† Thomas G. Ayers Professor of Energy Resource Management and Professor of Management Strategy, J.L. Kellogg Graduate School of Management, Northwestern University. We thank Ramose Betfarhad and Marshall Smith for their able research assistance. An earlier version of this Article was submitted by Mr. Sidak on behalf of the Canadian Competition Bureau to the Mandate Review of Canada Post Corporation in February 1996.

Copyright $(1997$ by the Yale Joumal on Regulation 
B. Cost Economies Do Not Justify Public Provision of Postal Services

C. Public Provision Is Not Needed to Ensure Ubiquity and Pricing Uniformity....

D. Public Provision Is Not Needed to Ensure the Integrity of the Mail Stream.

1. Private Provision of Secure Communications and Deliveries ..47

2. Reputational Effects of Criminal Wrongdoing or Negligence by Postal Employees ............................................................48

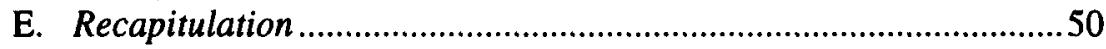

IV. The Competitive Problems of Postal Pricing and Regulations ................51

A. Preventing Anticompetitive Cost Misallocation by Canada Post ....51

1. The Logic of Price Caps .........................................................52

2. Price Caps and Canada Post ..................................................53

B. Incorrect Measurement and Misallocation of Attributable Costs....54

1. Cost-of-Service Regulation of the U.S. Postal Service ..............54

2. Tests for Cross-Subsidies in Multiproduct Firms ......................55

3. Attributable Costs and Institutional Costs ..............................56

4. The Difficulty of Preventing Cross-Subsidization by Canada Post.

5. Remedies for Cost Misallocation by Canada Post ....................62

C. Misuse of Ramsey Pricing Principles...........................................62

1. Ramsey Pricing ..................................................................62

2. The Error Underlying the GAO's Recommendation That the U.S. Postal Service Employ the Inverse Elasticity Rule

3. The Correct Demand Elasticity for Computing Ramsey Prices for the U.S. Postal Service ...........................................68

D. The U.S. Postal Service's Pursuit of "Profit".................................71

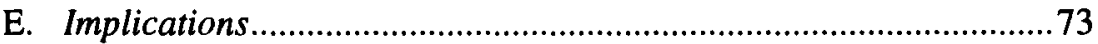

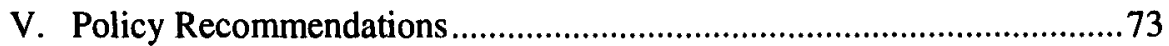

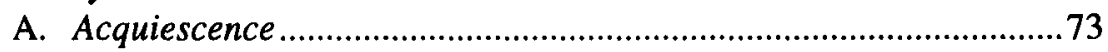

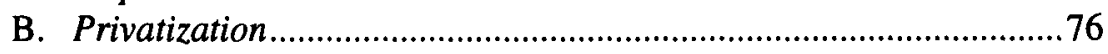

C. Commercialization .....................................................................77

1. Remove Canada Post's "Exclusive Privilege" and Any Other Explicit or Implicit Privileges of Public Ownership .......77

2. Relieve Canada Post of Its Universal Service Obligation and Other Incumbent Burdens ...............................................79

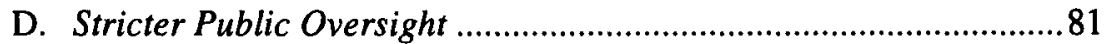

1. Establish a Regulatory Oversight Commission ........................81

2. Clarify That It Is Not Canada Post's Mission to Be a "Profit Center" for the Federal Government. 


\section{Introduction}

Mail delivery is one of the few economic activities that has avoided the wave of deregulation and privatization that has swept network industries over the past two decades. Nonetheless, postal services throughout the world are receiving critical reexamination, not only because of the technological developments that appear to be changing the essential character of communications, but also because of a growing body of experience and scholarly research concerning the regulation and public ownership of enterprise. Such experience and research now provides policymakers with a better understanding than they had a generation or more ago of the costs and benefits of the existing way in which postal services are produced. ${ }^{1}$ This Article builds on that experience and research by examining the following questions concerning the business activities of Canada Post Corporation (Canada Post) in a competitive environment: What should be the appropriate mandate of Canada Post? In particular, is Canada Post a natural monopoly and, if so, what form of regulation would best serve Canadian consumers? If the delivery of letter mail is not a natural monopoly, what basis exists for retaining Canada Post's current statutory monopoly? What potential exists for Canada Post to abuse its statutory monopoly-and other statutory privileges and immunities-to compete unfairly against efficient private suppliers of postal services?

Canada Post's "exclusive privilege" to provide letter mail protects Canada Post from competition in that particular market. Public ownership and control exempt Canada Post's actions from the corporate governance that is characteristic of private enterprises. Despite repeated findings that Canada Post does not take advantage of its autonomy and letter mail monopoly to subsidize its entry and expansion into competitive markets, such as parcel post and express mail, the existence of a government-owned monopoly that may participate in competitive markets perpetuates the potential for such abuse and raises a fundamental issue: whether Parliament's grant of a monopoly to Canada Post over the delivery of letter mail should be used to restrict or supplant private commerce in other markets. Even if no crosssubsidization or predatory pricing ever occurs, Canada Post clearly has an advantage over its competitors because it has in place a government-nurtured, nationwide delivery system that may yield synergies from the joint provision

1. See, e.g., J. Gregory SidaK \& Daniel F. Spulber, Protecting Competition from the POSTAL MONOPOLY (1996). 
of other communication, transportation, and delivery services. This Article examines the justifications for Canada Post's publicly protected postal monopoly and public ownership and control. The economic and legal analysis presented demonstrates that the extension of the postal monopoly into competitive markets should be prevented or, conversely, Canada Post's statutory monopoly over letter mail should be abolished and open competition in all communications services should be allowed.

Public provision of an essential service can be justified economically if policy makers can identify a market failure that prevents private provision of the service and if they can discern an important advantage that the government has in providing the service. Proponents of the public provision of letter mail by Canada Post, however, have failed to identify any such market failure. Postal services are far from being "public goods" because costs are sensitive to volumes, congestion externalities in production are present, and customer access can easily be excluded. Moreover, pricing of delivery services rations access to postal services, as it does with any privately provided product or service. The absence of market failure is also evident from the extensive services that private carriers of parcel post, express mail, and package delivery provide. The presence of multiple substitutes for public postal services-including telecommunications and facsimile, electronic mail, private carriers, and transportation-effectively mitigates any losses that might arise from some government advantage, however unlikely such an advantage may be.

The market failure that typically is used to justify public control of entry, although not necessarily public provision of a service, is that the market cannot achieve cost savings from natural monopoly. This discussion demonstrates that, although there may be some economies of scale and scope in postal delivery services, those economies are far from sufficient to argue for a protected monopoly for the services. Even if there were such a monopoly, firms providing the delivery of letter mail could be privately owned, as are public utilities.

The same reasons that favor private over public provision of postal services apply to the question of whether the government should compete with the private sector for providing those services. If the private sector can provide the services, there is no role for government in the market as supplier. Moreover, when the expansion of government provision of such services interferes with private provision, thus reducing opportunities for private concerns to recover their investments, government supply of postal services represents a taking of private property by interfering with ongoing commercial concerns.

Part I of this Article outlines the regulatory and institutional setting in which Canada Post operates, including the nature and extent of Canada Post's legal monopoly. Part II demonstrates why technological justifications for the 
postal monopoly are no longer valid. Part III establishes that public provision of the full range of postal services is no longer needed. Analogizing to experiences of the U.S. Postal Service, Part IV explains how postal pricing and regulation can cause competitive problems for private firms because of incorrect measurement and misallocation of attributable costs and because of the potential to misuse Ramsey pricing principles.

Part V presents four options that are available to Parliament for addressing the problem of protecting efficient competition from the postal monopoly. The first is for Parliament simply to acquiesce to Canada Post's current pattern of empire building. The second is to privatize Canada Post. The third is to commercialize Canada Post; that is, to turn Canada Post into a publicly-owned business free of any statutory privileges or burdens relative to private firms. The fourth is to allow Canada Post to retain its exclusive privilege and all other statutory privileges and burdens, but to subject it to far more rigorous public oversight. Commercialization may be the most attractive option because it is politically feasible and would appreciably enhance economic welfare.

The concern with protecting efficient competition from the postal monopoly figures prominently in the recently released report of the Canada Post Mandate Review (Review). ${ }^{2}$ In fact, the Review recommends withdrawal of Canada Post from "competition with the private sector in areas of activity outside its core public policy responsibilities for providing postal services."3 Specifically, the Review finds "that the competitive activities of Canada Post, based as they are on the foundation of the corporation's exclusive privilege and of the network it has built with public funds, are incompatible with basic principles of fairness." 4 It further finds "that the emphasis on competitive activities has distorted Canada Post's corporate culture and behaviour, diverting it away from a focus on the public service and public policy responsibilities that are the reasons for its existence."5 Moreover, the Review notes that the corporation's diversification into competitive markets has failed to produce financial gains. ${ }^{6}$

Even though the Review's recommendation charts a course significantly different from the one on which Canada Post currently is embarked, the rationale behind the recommendations essentially is devoid of economic analysis regarding the costs and benefits of regulated state monopolies. In contrast, this Article explicitly relies on economic analysis in examining Canada Post's participation in competitive markets.

2. THE RePORT OF the CaNada POST MANDATE REVIEW, THE Future of Canada Post CORPORATION 86 (July 1996) [hereinafter MANDATE REVIEW].

3. Id.

4. Id. at 77 .

5. Id.

6. Id. at 77-78. 


\section{The Existing Regulation of Canada Post}

After operating for more than a century as a department of the federal government, Canada's Post Office Department was converted in 1981 into a federal Crown corporation, thus establishing Canada Post Corporation. ${ }^{7}$ To ensure the continued viability of the organization, Parliament bestowed upon Canada Post a collection of privileges and immunities that make it unique among Canada's economic enterprises. Canada Post is wholly owned by the Canadian government, ${ }^{8}$ operates under a mandate to provide postal service to the entire country, ${ }^{9}$ is obligated to serve similar communities in like manner, ${ }^{10}$ and is, for the most part, free to set its own prices. ${ }^{11}$ Like other Canadian corporations, Canada Post can issue debt, ${ }^{12}$ is authorized to pay dividends to its shareholders, ${ }^{13}$ and is subject to the federal income tax. ${ }^{14}$ Closer scrutiny, however, reveals that Canada Post is privileged with regard to those burdens as well. Finally, unlike any other Canadian corporation, Canada Post has a statutory monopoly over letter mail. ${ }^{15}$

The effectiveness of existing legal and regulatory barriers to entry into mail delivery is evident. Canada Post is very large. In terms of sales, Canada Post ranks in the top fifty of Canada's largest companies. ${ }^{16}$ With annual sales for fiscal year (FY) 1994-95 reaching $\$ 4.7$ billion, Canada Post ranks significantly above other large Canadian communications companies, such as British Columbia Telephone, Teleglobe, and Rogers Communications. ${ }^{17}$ Despite its size and privileged status, Canada Post is not very profitable. In terms of net incom Canada Post ranks well below the top 500 Canadian companies. $^{18}$ It has earned a profit in only five of its fourteen years of existence; it suffered a net loss of $\$ 69$ million in FY 1994-95 and $\$ 270$ million in FY 1993-94. ${ }^{19}$

7. Canada Post Corporation Act, R.S.C., ch. C-10, § 4 (1985) (Can.).

8. CANADA POST CORP., 1995-1996 to 1999-2000 CoRPORATE Plan / 1995-1996 CAPITAL BUDGET 13 (1995) [hereinafter CANADA POST CORPORATE PLAN].

9. Canada Post Corporation Act, R.S.C., ch. C-10, $\$ 5$ (1985) (Can.).

10. $\S 5$.

11. $\$ 19$.

12. $\$ 28$.

13. $\$ 28$.

14. PRICE WATERHOUSE LLP, A STRATEgIC REVIEW OF PROGRessive POSTAL ADMINISTRATIONS: COMPETITION, COMmercialization, AND DEREgulation 13 (1995) [hereinafter PRICE Waterhouse STRATEGIC REVIEW].

15. Canada Post Corporation Act, R.S.C., ch. C-10, $\$ 14$ (1985) (Can.).

16. The Corporate 500, CAN. BuS., June 1993, at 69, 70.

17. Id.; CANADA POST CORP., 1994-1995 ANNUAL REPORT 36 (1995) [hereinafter CANADA POST ANNUAL REPORT]. Throughout this Article, all currency is in Canadian Dollars unless otherwise indicated.

18. The Corporate 500, supra note 16 , at 70 .

19. Canada Post Corp., Corporate Overview, Jun. 1996, available in INTERNET (enter "www.mailposte.ca/english/overview/overview.html\#profile"); CANADA POST ANNUAL REPORT, supra note 17 , at 35 . 
Canada Post serves more than twenty-eight million Canadians, more than 900,000 businesses and public institutions, numerous international customers, and more than 200 postal administrations around the globe. ${ }^{20}$ With more than 62,500 full- and part-time employees, a fleet of more than 6,000 vehicles, and twenty-three major mail processing plants, Canada Post handles more than eleven billion messages and parcels per year. ${ }^{21}$ It serves its customers through approximately 18,500 retail points of access. ${ }^{22}$

\section{A. The Mandate}

To assess the current circumstances of Canada Post and its plans for the future, one must understand the statutory objectives that were established for the company by Parliament. Under its mandate, as codified in the Canada Post Corporation Act (CPCA) of 1981, Canada Post is obligated:

(a) to establish and operate a postal service for the collection, transmission and delivery of messages, information, funds and goods both within Canada and between Canada and places outside Canada;

(b) to manufacture and provide such products and to provide such services as are, in the opinion of the Corporation, necessary or incidental to the postal service provided by the Corporation; and

(c) to provide to or on behalf of departments and agencies of, and corporations owned, controlled or operated by, the Government of Canada or any provincial, regional or municipal government in Canada or to any person services that, in the opinion of the Corporation, are capable of being conveniently provided in the course of carrying out the other objects of the Corporation. ${ }^{23}$

Canada Post is bound to fulfill those objectives while giving due consideration to the following:

(a) the desirability of improving and extending its products and services in the light of developments in the field of communications;

(b) the need to conduct its operations on a self-sustaining financial basis while providing a standard of service that will meet the needs of the people of Canada and that is similar with respect to communities of the same size;

(c) the need to conduct its operations in such manner as will best provide for the security of mail;

20. CANADA POST CORPORATE PLAN, supra note 8, at 2 .

21. Id.

22. Id.

23. Canada Post Corporation Act, R.S.C., ch. C-10, $\$ 5$ (1985) (Can.). 
(d) the desirability of utilizing the human resources of the Corporation in a manner that will both attain the objects of the Corporation and ensure the commitment and dedication of its employees to the attainment of those objects; and

(e) the need to maintain a corporate identity program approved by the Governor in Council that reflects the role of the Corporation as an institution of the Government of Canada. ${ }^{24}$

Thus, Canada Post is obligated to operate a nationwide postal service and is authorized to offer all services that are "necessary or incidental" to fulfilling that objective. That mandate is particularly broad in scope when one reads it in conjunction with the forward-looking provision (a) immediately above, which suggests the possibility that Canada Post must provide emerging communications services, such as e-mail and remote desktop publishing.

\section{The Social Mandate}

Canada Post's mandate addresses two aspects of postal service that are often cited as support for public ownership of postal enterprises: security of the mail and universal service. Although Canada Post must act to ensure the integrity of the mail stream, experience from the United States suggests that public ownership is not necessarily the best way to accomplish that goal. With respect to the second social goal, primarily because of the country's geographic expanse and its disparate population densities, Canada Post provides a modified form of universal service by providing like services for communities of similar sizes. Canada Post also offers letter mail at uniform rates, even though no statutory mandate requires it to do so. ${ }^{25}$

\section{The Financial Mandate}

Canada Post's mandate is clearly flexible in its operation. Although the mandate explicitly states that Canada Post is to be self-sustaining, the enterprise was not so for its first seven years of existence. With regard to financial viability, the CPCA operates in conjunction with other laws. As a Crown corporation, Canada Post is subject to the Financial Administration Act (FAA). Under section 3(5) of the FAA, Canada Post "must not be ordinarily dependent upon appropriations for operating purposes, must ordinarily earn a return on equity and must have a reasonable expectation of paying dividends." ${ }^{26}$ Until 1988, however, Canada Post was permitted to use

24. Id.

25. PRICE WATERHOUSE STRATEGIC REVIEW, supra note 14 , at 14.

26. Canada Post Corp., Canada Post Corporation: Competition and Regulation 14 (1995) [hereinafter COMPETITION AND REGULATION]. 
federal funds to cover the deficit when it operated at a loss. ${ }^{27}$ All funds that Canada Post received in that manner were to be "reimbursed to the Minister of Finance from the annual revenues of the Corporation in so far as such revenues [were] sufficient." 28 Since 1988, Canada Post has been financially self-sufficient in the sense that it has "no access to government funds or capital for operating shortfalls."29

Nevertheless, Canada Post still benefits from its government ownership. It may borrow directly from the federal government. ${ }^{30}$ It also may borrow private capital at rates more favorable than its private competitors can obtain because its debt is backed by the full faith and credit of the Canadian government. $^{31}$

Parliament also has nurtured Canada Post with certain tax advantages. Until FY 1994-95, Canada Post paid no federal income taxes, even when it earned positive net income, ${ }^{32}$ because it is exempt from such taxes. On March 27, 1994, however, the enterprise "becarne a prescribed Crown Corporation for tax purposes and as such is subject to federal income taxation under Part 1 of the Income Tax Act." ${ }^{\text {"33 }}$ Canada Post also enjoys the benefit of consolidated tax loss carry-forwards in the amount of $\$ 320,000,000$, which are available to reduce future income taxes and will not expire until $2002 .{ }^{34}$ Despite having $\$ 4.7$ billion in revenue, Canada Post paid only $\$ 5$ million in taxes for FY $1994-95$; by 2000 , it expects to generate $\$ 5.83$ billion in revenue and have a tax liability of only $\$ 19$ million. ${ }^{35}$

Canada Post is authorized to issue shares and pay dividends. That aspect of corporate governance, however, has not put Canada Post on equal ground with private Canadian corporations. Rather, it has highlighted the unique status of the enterprise. In 1993, Parliament amended the CPCA to authorize Canada Post to issue as many. shares as it sees fit. The amendment is of little practical effect, however, because the government currently owns all the shares in Canada Post and will always hold all voting rights under the present statutory scheme. The amendment does allow Canada Post to issue up to 10 percent of all outstanding shares to its employees ${ }^{36}$ and authorizes Canada Post to declare and pay dividends. ${ }^{37}$ Again, that provision is of little practical effect apart from the possibility that someday employee shareholders may receive a dividend. According to Price Waterhouse, Canada Post "pays

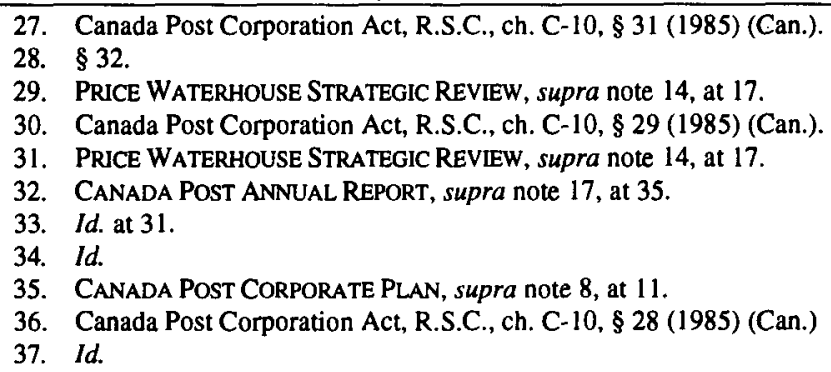


dividends to the government when it earns a positive net income; . . . [t]he last time it paid a dividend was in FY 1992-1993."38 In its projected statement of income and retained earnings, however, Canada Post estimates positive net income over the next three years but accounts for no dividends until $1999 .{ }^{39}$ Canada Post has indicated in its projected balance sheet that it may issue its first shares to employees in $1999 .^{40}$

Finally, the government gives many direct subsidies to Canada Post. The federal government pays Canada Post for "publications, Parliamentary mail, literature for the blind, and the shipment of food and similar items to the North. ${ }^{, 41}$ In 1994, the federal government compensated Canada Post $\$ 114.9$ million for foregone revenue from those sources. ${ }^{42}$ Yet, the most significant subsidy - the one that sets Canada Post apart from most of its competitors-is federal funding of Canada Post's pension plan. According to Price Waterhouse: "[Canada Post's] employees are part of the Canadian federal government's pension plan. From [Canada Post's] perspective, any unfunded liability is an obligation of the federal government., ${ }^{, 43}$ In that manner, the federal government implicitly subsidizes Canada Post's cost of labor, just as it explicitly subsidizes the firm's cost of capital.

\section{The Statutory Monopoly}

Under the CPCA, Canada Post "has the sole and exclusive privilege of collecting, transmitting and delivering letters to the addressee thereof within Canada." ${ }^{44}$ Not included within Parliament's definition, and therefore not within the scope of Canada Post's exclusive privilege, are newspapers, magazines, books, catalogs, and goods. ${ }^{45}$ The exclusive privilege does not apply to "letters of an urgent nature that are transmitted by a messenger for a fee at least equal to an amount that is three times the regular rate of postage payable for delivery in Canada of similarly addressed letters weighing fifty grams" or "letters in the course of transmission by any electronic or optical means. ${ }^{, 46}$ So, the major markets that are open to competition are parcel post, express mail, and electronic or optical communications. Any person who contravenes Canada Post's exclusive privilege over letter mail is guilty of a crime, punishable by imprisonment. ${ }^{47}$ Canada Post, however, implies that it is not concerned with enforcing its monopoly. "A recent Canada Post

\footnotetext{
38. PRICE WATERHOUSE STRATEGIC REVIEW, supra note 14, at 15.

39. CANADA POST CORPORATE PLAN, supra note 8, at 11.

40. Id. at 11,13 .

41. Price Waterhouse Strategic Review, supra note 14, at 14.

42. Id.

43. Id. at 17 .

44. Canada Post Corporation Act, R.S.C., ch. C-10, § 14 (1985) (Can.).

45. Id.

46. \& 15 .

47. $\S \S 56,60$.
} 
publication noted that a taxi company was competing with [Canada Post] in Calgary and Edmonton for delivery of letters." ${ }^{48}$ The taxi company delivers standard mail for $35 \not$, significantly lower than Canada Post's rate of $45 \notin .{ }^{49}$

\section{B. Competition}

With all its privileges and immunities, Canada Post today finds itself confronting a daunting reality. The enterprise acknowledged in 1995 that it "is already experiencing erosion of some Lettermail volumes to electronic funds transfer, automatic account debiting and electronic messaging such as facsimile transmission and electronic mail." ${ }^{, 0}$ Discussing the period just before its conversion to Crown corporation status, Canada Post stated: "Competition in the form of courier companies, facsimile machines, direct funds transfer and telecommunications firms sprang up to take away the premium parts of the postal business." ${ }^{, 51}$ In testimony before the U.S. Congress in January 1996, Canada Post's president and chief executive officer Georges Clermont called for an unfettered ability to adapt: "Postal services are no different than other corporations or organizations, to survive they have to be relevant." 52

Mr. Clermont's remark cuts to the very reason for Canada Post's existence. In an era of rapid technological change and competitive substitution, one can read the remark as an acknowledgement of the decreasing relevance of Canada Post's traditional business-the collection, transport, and delivery of letter mail-and the need to reconsider Canada Post's mandate. Should Canada Post participate in competitive businesses and expand into emerging ones so long as the government owns the company or, at the very least, the company retains a statutory monopoly over letter mail?

\section{Traditional Services and Aggressive Expansion}

Canada Post provides services that range from traditional letter mail and parcel post to recent innovations in which Canada Post acts as the link between businesses with electronic capabilities and those that continue to rely on paper-based information.

48. PRICE WATERHOUSE STRATEGIC REVIEW, supra note 14, at 15.

49. Supra note 19.

50. Canada POST CORPORATE PLAN, supra note 8, at 7.

51. Supra note 19.

52. Hearing Before the Subcomm. on the Post Office and Civil Service of the Senate Comm. on Gov't Affairs and the Subcomm. on the Postal Service of the House Comm. on Gov't Reform and Oversight, 104th Cong. (1996) (statement of Georges C. Clermont, President and Chief Executive Officer, Canada Post Corp.) [hereinafter Clermont Testimony]. 
Canada Post offers traditional postal services such as the delivery of letter mail, parcels, express mail, publications, and advertisements. "Letter mail is defined as letters, postcards or similar communications completely or partially typewritten or handwritten, receipts, invoices or similar financial statements relating to a specified sum of money, or any other mail that the sender chooses to mail at the Lettermail rates of postage." 53 Lettermail in Canada is subject to delivery standards: two days for local delivery, three for in-province delivery, and four for out-of-province delivery.

For package delivery throughout Canada, Canada Post offers its Regular Post as the "lowest priced parcel service in Canada" and has delivery standards of three days for local shipments, four to five days within a province, and four to thirteen days for national shipments. ${ }^{54}$ Canada Post offers overnight service itself and through its subsidiary, Purolator Courier. Boasting of a network with which "no other courier company can compare," Canada Post offers its overnight service under the name Priority Courier. ${ }^{55}$ Purolator, one of Canada's largest overnight couriers, handles more than 300,000 envelopes and parcels each night. It operates such branded services as Weekender, USA.M., and 9AM DayStarter, and offers assurance to its customers with a scanning and tracking system called Purotrakker. ${ }^{56}$ Canada Post also offers a medium speed, medium price, expedited service called Xpresspost. $^{57}$

In an effort to generate new business, Canada Post has forayed into a variety of new services, including hybrid mail options, desktop publishing, and electronic commerce. ${ }^{58}$ Unrestrained by its broad mandate to provide any services incidental to postal service and to consider the developing technologies of communication, Canada Post has aggressively developed new service products to add value to its traditional distribution services. In fact, Canada Post sees such vertical integration as essential to its survival. Canada Post anticipates that, "[w]ith the convergence of computers, electronic communication and interactive television, [it] will position itself to deploy electronic network services that will complement and be integrated with its extensive physical network." 59

53. Canada Post Corp., Consumer Services Within Canada, Dec. 10, 1996 available in INTERNET (enter “www.mailposte.ca/english/postservice/canada.html\#priority courier”).

54. Id.

55. Id.

56. Purolator Courier Ltd., Corporate Profile, Dec. 10, 1996 available in INTERNET (enter "www.mailposte.ca/english/electronic/hybrid.html\#mail").

57. Canada Post Corp., Consumer Services Within Canada, Dec. 10, 1996 available in INTERNET (enter "www.mailposte.ca/english/postservice/canada.html\#priority courier").

58. Canada Post Corp., Hybrid Mai, Dec. 10, 1996 available in INTERNET (enter "www.mailposte.ca/english/electronic/hybrid.html\#mail").

59. CANADA POST CORPORATE PLAN, supra note 8 , at 7. 
Through its OmniPost service, Canada Post offers point-to-point communication via e-mail, faxmail, or lasermail. ${ }^{60}$ With faxmail, Canada Post receives the customer's electronically transmitted message and transmits it to the designated recipient's fax machine. With Lasermail, Canada Post receives the customer's document in electronic form, transmits it to its own outlet closest to the recipient's location, and delivers a hardcopy of the document overnight.

Canada Post has developed several services to accommodate point-tomultipoint communications as well. To accommodate direct marketers, Canada Post has created two services that take advantage of the company's extensive distribution system and its databases on the Canadian population. Canada Post's GeoPost Target Marketing service offers informational assistance to direct marketers. ${ }^{61}$ Canada Post presumably is selling and analyzing the demographic information that it has accumulated from years of serving the public. In FY 1994-95 Canada Post launched its ProMedia service that takes a customer's camera-ready artwork, "determines the optimum target market, arranges the printing, prepares and handles the mailing."62 Canada Post apparently subcontracts the printing service.

In addition, Canada Post offers Electronic Lettermail and Electronic Admail, two related, new product lines that offer an alternative means of producing and delivering invoices, statements, time-sensitive notes (Electronic Lettermail), and direct marketing advertising mail, solicitations, notices, and bulletins (Electronic Admail). ${ }^{63}$ From information supplied by customers in electronic form (such as mailing lists, transactional data, and messages), Canada Post produces the customer's mailing pieces (with customer approval of proofs) and transmits the material electronically to its regional production centers, where the material is printed, inserted into envelopes, sorted, and delivered. ${ }^{64}$ The system is designed to save the subscriber time and effort by bypassing normal sorting and handling, speeding up production and reducing bottlenecks, and freeing up the customer's labor force.

Canada Post also offers Remote Desktop Publishing, which is similar to Lettermail Plus and Admail Plus in that the service takes the customer's documents in electronic form and prints, stuffs into envelopes, and delivers newsletters for businesses and organizations that mail frequently to large customer mailing lists. ${ }^{65}$

Finally, Canada Post has begun to enter businesses entirely unrelated to the traditional collection, transportation, and delivery of letters and goods. For

60. Hybrid Mail, supra note 58.

61. CANADA POST ANNUAL REPORT, supra note 17, at 15.

62. Id.

63. Hybrid Mail, supra note 58.

64. Id.

65. Id. 
example, Canada Post is part of a consortium, known as UBI, that is conducting an interactive television pilot project that allows customers in 34,000 homes to purchase goods, pay bills, and receive e-mail from home. ${ }^{66}$ In conjunction with Canadian Imperial Bank of Commerce, Canada Post intends to offer automatic teller machines in certain corporate retail outlets. ${ }^{67}$

\section{Limiting Mailbox Access}

Canada Post does not have a statutory monopoly over access to the customer's mailbox as the Postal Service does in the United States. ${ }^{68}$ Pursuant to its mandate to ensure the integrity and security of the mail stream, however, Canada Post controls access to all locked mailboxes and mailboxes in most apartment buildings. ${ }^{69}$ This privilege is of growing concern to existing and potential participants in competitive mail service markets because Canada Post has embarked on a major campaign to install cluster mailboxes in communities throughout the country. ${ }^{70}$ According to Canada Post, community mail boxes and kiosks now serve approximately 1.4 million addresses. ${ }^{71}$ Canada Post readily acknowledges that the increased use of the community mailboxes is designed to help reduce the allegedly rising costs of home delivery. What Canada Post fails to acknowledge is that the increased use of community mailboxes establishes a de facto monopoly over access to an increasing number of customers' mailboxes.

The existence of a monopoly over access to a customer's mailboxwhether it is de jure, as in the United States, ${ }^{72}$ or de facto, as is emerging in Canada-has three significant economic consequences. First, it enables Canada Post to raise the cost of its rivals' deliveries. Second, it deters vertical integration into mail delivery by businesses (such as newspapers and utilities) with large numbers of routine mailings to virtually every postal customer on a given route. Third, it raises the cost to the customer of substituting alternative delivery services for those of Canada Post.

Those implications of control over access were at the heart of a recent legal challenge brought by some of Canada Post's competitors. In June 1995, the Federal Court of Canada held that "there is no question Canada Post acted within its parliamentary mandate when delivering flyers to apartment building

66. CANADA POST ANNUAL REPORT, supra note 17, at 4.

67. PRICE Waterhouse Strategic ReVIEW, supra note 14 , at 16.

68. Hearing Before the Subcomm. on the Post Office and Civil Service of the Senate Comm. On Gov't Affairs and the Subcomm. on the Postal Service of the House Comm. on Gov't Reform and Oversight, 104th Cong. (1996) (statement of Michael E. Motley, Associate Director, Govemment Business Operations Issues, General Gov't Div., U.S. General Accounting Office) [hereinafter Motley Testimony].

69. PRICE WATERHOUSE STRATEGIC REVIEW, supra note 14 , at 15.

70. CANADA POST CORPORATE PLAN, supra note 8 , at 2.

71. Id.

72. 18 U.S.C. $\S 1725$ (1994). 
mailboxes. . . .73 The court thus dismissed an application, filed a month earlier by several companies competing with Canada Post in the market for delivery of unaddressed advertising mail, that sought an order to prohibit Canada Post from using its control over access to locked apartment mailboxes to deliver unaddressed admail. The applicants-Canadian Daily Newspaper Association (CDNA), ${ }^{74}$ Metroland Printing, Publishing \& Distribution Ltd., Netmar Inc., and Les Messageries Publi-Maison Ltee.-complained that Canada Post was "[u]nlawfully exploiting its control over access to locked apartment mail boxes in order to give its unaddressed Admail service an undue competitive advantage over private sector competitors in the distribution of unaddressed advertising materials to consumers."75 According to CDNA's president:

Canada Post's practices with regard to apartment access deprive the members of the CDNA and the other applicants of the ability to compete with Canada Post on equal terms for the distribution business of advertisers, many of whom insist that their unaddressed flyers reach apartment dwellers on a guaranteed and comprehensive basis . . . . This unwarranted extension of Canada Post's monopoly costs the members of the CDNA and the other applicants substantial revenue in terms of both lost and potential business . . . [ [ ] is imperative that competition take place on equal terms. Canada Post should not be permitted to leverage its statutory powers in order to achieve an unfair advantage over its private sector competitors. That is not consistent with the wording or intention of the Canada Post Corporation Act. $^{76}$

Canada Post's senior vice president of operations countered: "Access to these boxes is granted to the corporation by the landlord of the building. We deliver mail to these boxes because they are secure, but if access is granted to other delivery companies, the security of the mail would be compromised."77

73. Federal Court of Canada Finds Canada Post Acting Within Parliamentary Mandate When Delivering Flyers, CAN. NEWsWIRE, June 23, 1995, available in LEXIS, Nexis Library [hereinafter Canada Post Acting Within Parliamentary Mandate].

74. The CDNA is a member service organization serving 84 of the 107 daily newspapers in Canada. CDNA members account for approximately $86 \%$ of newspapers distributed daily across Canada. CDNA members distribute unaddressed flyers either as inserts in their newspapers to newspaper subscribers or to non-subscribers as standalone items through various forms of extended market coverage vehicles. The other applicants carry on various businesses including the delivery of unaddressed advertising flyers, either as inserts in controlled-distribution community newspapers or on a stand-alone basis. Canadian Daily Newspaper Association-CDNA Takes Canada Post to Court, CAN. NEWSWIRE, May 12, 1995, available in LEXIS, Nexis Library [hereinafter CDNA Takes Canada Post to Court].

75. Canada Post Acting Within Parliamentary Mandate, supra note 73.

76. CDNA Takes Canada Post to Court, supra note 74 (remarks of John E. Foy). Blanchette).

77. Canada Post Acting Within Parliamentary Mandate, supra note 73 (remarks of Leo 
In his opinion, Mr. Justice Cullen stated:

My finding that unaddressed Admail constitutes "mail," combined with the fact that there is no express statutory prohibition against delivery of Admail, leads me to the conclusion that Canada Post has not exceeded its jurisdiction ... Putting flyers into mailboxes, even if they are not letters per se, is an undertaking which is clearly incidental to Canada Post's mandate and not an act in excess of its jurisdiction. $^{78}$

He concluded that "[t]he applicants' argument is flawed because it makes illogical connections between access to mailboxes and the delivery of flyers." 79 Mr. Justice Cullen said: "I have no doubt apartment dwellers would not feel comfortable with many people having access to mailboxes, especially given the number of cheques and credit cards which are sent by the post. It is clear to me that Canada Post takes its duty to provide security of the mail seriously ... I I do not find that Canada Post has used its custody over apartment mailbox keys or its monopoly over the delivery of letters for an improper purpose." 80

The court clearly accepted Canada Post's argument that access to the apartment building mailboxes has great security implications, presumably because access to a single mailbox in an apartment building often can be obtained only along with access to all the building's mailboxes. ${ }^{81}$ It may be true that there is a greater risk associated with more open access to such mailboxes when compared with access to a home's mail slot. But, it is difficult to see any greater threat to security associated with more open access to such mailboxes than already exists with respect to the present access to mailboxes outside a customer's premises. Without assessing any further considerations of policy, the Federal Court decided the issue strictly by comparing Canada Post's mandate and its questioned activities. A Canada Post news release stated that the Federal Court found the delivery of admail to be entirely consistent with, and in fact an advancement of, "the generally beneficial result of expanding postal services to meet the needs of Canadian businesses and advertisers, of becoming financially self-sustaining, and of ensuring for the security of the mail. . .."82 Delivering unaddressed mail

78. Id.

79. Id.

80. Id.

81. The same, of course, holds true for Canada Post's community mailboxes. A challenge to Canada Post's domain over those mailboxes, however, would meet with even greater resistance from the court because they are the property of Canada Post.

82. Court Favors Canada Post over Torstar on Junk Mail, CAN. FIN. REP., June 23, 1995, available in LEXIS, Nexis Library. 
appears to fall within the broad scope of Canada Post's mandate, as discussed earlier.

In its report, the Canada Post Mandate Review disagrees with the conclusion that the delivery of unaddressed admail is within the scope of Canada Post's core postal service mandate. Consequently, the Review recommends that Canada Post withdraw from the unaddressed admail delivery business. The Review reasons that Canada Post's aggressive competition in the unaddressed admail market is a "clear instance where a distortion is created by applying to competitive commercial purposes the unrivalled market power and privilege that Canada Post derives from its public sector monopoly position." ${ }^{83}$ Thus, the Review finds that the corporation's "exclusive access to apartment mailboxes for the delivery of unaddressed admail constitutes an unfair competitive advantage for Canada Post over the private sector." 84 As for the decision in the CDNA case, the Review notes that Mr. Justice Cullen's dismissal of the case was based "on the legal grounds that the corporation has not exceeded its parliamentary mandate by delivering admail to apartments, nor has it engaged in legally improper activity." ${ }^{85}$ But the Review concludes that the real issue in the case was not one of legality; rather, it was an issue of fairness.

As Canada Post builds more and more community mailboxessometimes over the objections of the very communities that such boxes are intended to serve ${ }^{86}$ - it increasingly forecloses competition in postal services, such as the delivery of unaddressed admail. The costs incurred to consumer welfare call for a revised approach. Because there are significant costs associated with Canada Post's increasingly pervasive de facto monopoly over mailbox access, Parliament may wish to reconsider the impact of its policy.

Parliament need not open community mailboxes and apartment building mailboxes to the general public. Parliament could implement a licensing scheme whereby a bonded provider of mail services would be required to obtain a license for access to the community or apartment mailboxes. These licenses could limit access to particular times of day. Parliament could make the licenses marketable to other bonded entities.

\section{Labor}

Labor costs are the largest component of Canada Post's total operating costs. ${ }^{87}$ One estimate puts total labor costs, "including wages and benefits, employment levels and job security, and negotiated work practices," at

83. MANDATE ReVIEW, supra note 2, at 29.

84. Id.

85. Id.

86. Douglas K. Adie, The mail Monopoly: analysing Canadian postal Service 10 (1990).

87. CANADA POSt ANNUAL REPORT, supra note 17 , at 23 
approximately $75 \%$ of Canada Post's operating costs. ${ }^{88}$ Canada Post holds the distinction of according its letter carriers "the absolute right to travel to and from their base on the corporation's time for their lunch break, even in some instances by paid taxi. ${ }^{, 89}$ In his evaluation of Canada Post's financial position for the Review, Gordon Ritchie, a former federal Deputy Minister and Deputy Chief Negotiator of the Canada-U.S. Free Trade Agreement, concludes that:

The Canadian Union of Postal Workers has been remarkably successful over the past 30 years in arrogating to its members the lion's share of economic rents from the Canada Post monopoly .... . The existing Canada Post Corporation collective agreements constitute what is arguably the most uncompetitive and inefficient labour agreement currently in place in any jurisdiction in North America .... It should be noted that excessive wages are not the main problem. Pay for time not worked is an even more substantial direct cost burden. The most costly provisions over the long run are probably those restricting the Canada Post Corporation's ability to terminate, to redeploy or to employ more efficiently its huge workforce. ${ }^{90}$

The existence of the Canadian postal service, both as the Post Office Department and as Canada Post, has been marked by a history of strained labor relations. In the twenty-six-year period from 1965 to 1991, Canadian postal workers went on strike twelve times. ${ }^{91}$ During a prolonged strike in 1991, relations between management and the union were said to have deteriorated "to the point of contempt, if not palpable hatred." 92 Since its 1981 transformation from a government department to a Crown corporation, Canada Post has tried to be more like a private business; as a result, it has attempted to cut costs, including labor costs. A concomitant consolidation in labor representation-four bargaining units now represent over $90 \%$ of Canada Post's employees ${ }^{93}$ - has provided the postal worker unions with added leverage to resist Canada Post's attempts to change. ${ }^{94}$

The consolidated representation has succeed in securing certain benefits for postal workers at the expense of Canada Post and Canadian consumers. The most significant benefit is that all unionized employees have job security:

88. MANDATE REVIEW, supra note 2, at 97.

89. Id. at 96.

90. Id. at 97 .

91. Brian Bergman, Trouble in the Mail: Canada Post's Problems Are Deep-Seated, MACLEAN's, Sept. 2, 1991, at 19.

92. Canada: Management and Unions Far Apart on Key Issues of Job Security, REUTER TEXTLINE FIN. POST, Aug. 27, 1991, available in LEXIS, World Library, Txtlne File.

93. CANADA POST CORPORATE PLAN, supra note 8, at 3.

94. Bergman, supra note 91 , at 19. 
they cannot be laid off. ${ }^{95}$ The Review observes that " $[t]$ here is no readily apparent reason . . . why Canada Post workers should enjoy virtually unconditional job security when it is not available to other Canadians in the public or private sectors." $"$ The power of the postal worker unions to extract such a concession casts serious doubt over whether Canada Post can ever be the lowest-cost provider of competitive postal services. Canada Post's chief executive officer acknowledges that guaranteed employment, as it results in part from the statutory monopoly, restrains the firm's ability to adapt and contributes to complacency in its work force: "[The employees] know that they have contractually obtained job security and that the Post office is not about to disappear. A normal corporation has a choice of shutting down an operation: we don't have that choice and it is evident in our workforce's behaviour." 97 In FY 1994-95, Canada Post's level of absenteeism averaged 9.9 days per employee, representing a cost to Canada Post of approximately $\$ 55$ million. $^{98}$

For Canada Post, labor costs continue to rise, even though purportedly there no longer exists a premium built into its wage schedule. From FY 199394 to FY 1994-95, Canada Post reduced its total workforce by 302 employees, but concurrently increased the number of full-time employees by more than that number. The result was a net increase in labor expenditures (measured in millions of hours paid) of 5\%. ${ }^{99}$ According to Price Waterhouse, "[w]age premiums had become inherent in the post office wage structure for three reasons: (1) monopoly, (2) essential service, and (3) government management." ${ }^{100}$ Canada Post, however, claims that a premium in basic wage rates no longer exists and that wage rates are comparable to industry norms. ${ }^{101}$ The corporation has indicated that some non-wage premiums remain, regarding working conditions and rules that deal with overtime and part-time and casual labor. ${ }^{102}$ Canada Post also has been trying to redistribute work hours from night to day and from weekends to weekdays, particularly during the summer. ${ }^{103}$

Finally, two other details about Canada Post's workforce point to its unique status as a public enterprise and demonstrate how it attempts to modify its cost structure when expanding in competitive businesses, given its labor relations. As noted earlier, Canada Post's employees are part of the federal government's pension plan; therefore, the pension is not Canada

95. Price Waterhouse Strategic ReVIEW, supra note 14 , at 16 .

96. MANDATE REVIEW, supra note 2, at 96.

97. Clermont Testimony, supra note 52.

98. CANADA POST ANNUAL REPORT, supra note 17 , at 10.

99. CANADA POST CORPORATE PLAN, supra note 8, at 36.

100. Price Waterhouse Strategic ReVIeW, supra note 14, at 17.

101. In 1995, on average, letter carriers eamed $\$ 16.07$ per hour, motorized mail drivers earned $\$ 16.51$ per hour, and mail handlers earned $\$ 16.50$ per hour. Id.

102. Id.

103. CANADA POST ANNUAL REPORT, supra note 17, at 10. 
Post's liability. ${ }^{104}$ Canada Post has hired a separate work force, earning much lower wages than regular letter carriers, to deliver unaddressed admail, usually on weekends. ${ }^{105}$

Labor relations have been one of the most troublesome hindrances in Canada Post's attempt to shed its inherited inefficiencies and compete in a dynamic industry. The Review notes the importance of the labor issues by stating that "no strategic repositioning of the corporation can fail to address these [labor] issues." 106 It thus recommends that "a more realistic set of arrangements be negotiated through a process of bargaining in good faith, illuminated by an understanding of the new realities of the Canadian workplace." 107

\section{Pricing and Costing: Policy and Disclosure}

Under Canadian laws of general application and Canada Post's explicit statutory mandate, Canada Post is prohibited from abusing its statutory monopoly to benefit its competitive businesses. Canada Post, however, sets its own rates and, in the view of its competitors, exploits the lack of a disclosure requirement in the ratemaking process to the detriment of efficient rivals.

The Competition Act prohibits a "broad range of anticompetitive conduct, including predatory pricing and abuses by corporations of dominant positions they may have in any class or species of business in any area of Canada." 108 Under the CPCA, Canada Post must set rates that are "fair and reasonable and consistent so far as possible with providing a revenue, together with any revenue from other sources, sufficient to defray the costs incurred by the Corporation in the conduct of its operations under this Act."109 Parliament has not established a third-party regulatory body to govern the rates implemented by Canada Post, even though the enterprise enjoys a statutory monopoly. Canada Post is authorized to devise its own regulations prescribing its postal rates, with the approval of the Governor in Council. ${ }^{110}$ To receive such approval, Canada Post must first publish its rate change proposals in the Canada Gazette for sixty days. All interested parties may then make presentations to the Minister responsible for Canada Post. Final proposed regulations are submitted to the Governor in Council for approval. As Canada Post explains, the "formal external rate regulation approval process is now limited, in large part, to letter mail products which fall within the ambit of Canada Post's exclusive privilege and which do not

104. PRICE WATERHOUSE STRATEgIC ReVIEW, supra note 14 , at 17.

105. Id. at 15 .

106. MANDATE REVIEW, supra note 2, at 97.

107. Id. at 99 .

108. COMPETTION AND RegUlation, supra note 26, at 11 .

109. Canada Post Corporation Act, R.S.C., ch. C-10, $\$ 19$ (1985) (Can.).

110. COMPETTION AND REGULATION, supra note 26 , at 16. 
involve incentives for volume tenderings and mail preparation." 111 All other rates are set by either generic or specific contracts. ${ }^{12}$ In addition, Canada Post can offer bulk discounts and "experimental services for three years without seeking government approval of rates."

Canada Post's ratemaking process lacks the transparency usually associated, at least in its aspirational form, with the traditional public utility commission that has jurisdiction over a regulated monopolist. ${ }^{114}$ As Price Waterhouse notes, "[s]ince the rate setting process is not public, interested parties do not have access to the costing studies and other information underlying the rates." "115 The Review observes: "Despite the understandable concerns that a corporation in its unique position might be using revenues from its monopoly to cross-subsidize unfairly low-prices for its competitive activities, Canada Post invokes 'commercial sensitivity' in refusing to publicly release detailed cost profit information for its various products and services." 116 This lack of disclosure prompts competitors to claim that Canada Post cross-subsidizes its competitive businesses with revenues from its statutorily protected businesses. In a report prepared for the Review, Canada Post assures that it "has consistently interpreted this mandate to mean that the prices of its exclusive privilege services must be such as to ensure that revenues generated from those services are not utilized to cross-subsidize the provision by Canada Post of concessionary or competitive services."117 Canada Post further declares that "the rates of its competitive products or services exceed the average incremental costs" and that the firm complies with the requirement to set its prices for competitive and commercial products "on a basis which will maximize their contribution in a competitive environment."118 Finally, Canada Post explicitly states that its competitive and commercial products "are not cross-subsidized, in any way, by revenues generated by Canada Post through the provision of exclusive privilege services." 119

The Review, on the other hand, finds that "Canada Post . . . does not have accounting systems that identify the actual costs and revenues of each specific product and service with satisfactory precision . . .."120 The Review notes that Canada Post uses a method that "consists of allocating variable and

111. Id. at 17

112. Robert Albon, Postal Rate-Making Procedures and Outcomes in Various Countries, in COMPETITION AND INNOVATION In Postal. SER vices 233, 236 (Michael A. Crew \& Paul R. Kleindorfer eds., 1991).

113. PRICE Waterhouse Strategic Review, supra note 14, at 15.

114. Traditional public utility commissions include such agencies as the Federal Communications Commission, Federal Energy Regulatory Commission, and state public utility commissions.

115. PRICE WATERHOUSE STRATEgIC ReVIEW, supra note 14 , at 15.

116. MANDATE REVIEW, supra note 2, at 21.

117. COMPETITION AND REGULATION, supra note 26, at 17.

118. Id.

119. Id.

120. MANDATE REVIEW, supra note 2, at 21. 
specific fixed costs to each product line, but leaving common fixed costs unallocated because the corporation says they would remain unchanged if any one product or product group were removed." ${ }^{, 21}$ Canada Post fails to allocate approximately $40 \%$ of its total costs. ${ }^{122}$ In examining Canada Post's nonallocated cost categories, the Review finds that the corporation's Activity Based Costing accounting system (ABC) accords Canada Post "considerable latitude to exercise discretion in deciding what should or should not be included in the definition of incremental costs." ${ }^{\text {"23 }}$ Moreover, the Review opines that Canada Post's utilization of the ABC system, the purpose of which is to distinguish between common network and incremental costs of providing a product, is colored by Canada Post's incentive to understate its incremental costs and overstate its common or non-allocated costs. The Review observes that misallocations occurred as a result of Canada Post's incentive-motivated accounting. For example, Canada Post's treatment of the concept of time in determining long-run incremental costs is one of the discretionary methodologies that led to cost misallocations. ${ }^{124}$ Other instances of misallocation stemmed from "how causal links between products and activities were identified or ignored" by the corporation's accounting. ${ }^{125}$ Ultimately, the Review finds that "[ $t]$ o the extent that cost misallocation is a form of cross-subsidization, . . . Canada Post has cross-subsidized."126

\section{The Purolator Acquisition}

In 1993, Canada Post purchased 75\% of Purolator Courier Ltd. from Onex Corporation for $\$ 55$ million. ${ }^{127}$ The Canadian Courier Association and some of its members objected to the acquisition, arguing that the acquisition would enable Canada Post to abuse its resulting dominance in the market and to cross-subsidize its courier business. At the time of the acquisition, Purolator was estimated to control $43 \%$ of Canada's courier market, while Canada Post controlled less than $10 \% .{ }^{128}$ Thus, Canada Post's expanded courier operations would account for approximately a 50\% share of a market approaching \$2 billion. ${ }^{129}$ Canada Post's chief executive officer dismissed allegations that the enterprise would cross-subsidize its private courier business with its letter mail monopoly: "The concern is without any foundation since Purolator Courier Ltd. will remain a separate commercial tax-paying enterprise with its own management, employees, operations and

121. Id.

122. Id.

123. Id. at 44 .

124. Id. at $44-45$.

125. Id. at 45 .

126. Id.

127. Robert Gibbens, Canada Post Buys Courier Stake, Fin. Times, June 7, 1993, at 17.

128. Richard Siklos, Canada Post in Talks to Buy Purolator, FIN. POST, June 1, 1993, at 1.

129. Id. 
service products." 130 Under the terms of the final agreement, Purolator was to remain a separate entity only until December 31, 1996.

Two government agencies dismissed the allegations brought by opponents to the acquisition. They held that the combined operations of the two companies would not significantly lessen competition in the Canadian courier market. In arriving at its conclusion, the National Transportation Agency accepted $31 \%$ as the accurate estimate of combined market share. ${ }^{131}$ The Bureau of Competition Policy further held that there existed insufficient evidence to prove that Canada Post would cross-subsidize its courier operations with monopoly profits. ${ }^{132}$ The Bureau accepted $40 \%$ as its estimate of combined market share-not enough in its view to enable Canada Post to sustain cross-subsidization and predatory pricing. ${ }^{133}$

In defense of its expansion in the competitive courier market, Canada Post cited its need to stay competitive with large private American couriers, such as Federal Express, United Parcel Service, and DHL International. Mr. Clermont said that "the market is not so much east and west as north and south."134

\section{The Bureau of Competition Policy's Analysis}

Opponents of Canada Post's acquisition of Purolator expressed concern over two issues. They claimed that it was inappropriate for a Crown corporation participating in a competitive market to acquire a competing company to strengthen its own market position, and they asserted that the acquisition would give Canada Post the ability to cross-subsidize its courier operations with the returns from its statutory monopoly. ${ }^{135}$ Federal Express Canada, for example, called for the creation of a regulatory mechanism to prohibit cross-subsidization and exploitation of unfair competitive advantage. ${ }^{136}$

In its review of the merger under the Competition Act, the Bureau of Competition Policy concluded that it did not have a basis upon which to challenge the transaction. The Acting Director of Investigation and Research, George Addy, determined that the issue "[w]hether Crown corporations

130. Richard Siklos, Post Office to Keep Purolator Separate, FN. POST, June 5, 1993, at 3.

3.

131. Janet McFarland, Couriers Fight on as Purolator Sale Ok'd, FIN. POST, Sept. 30, 1993, at

132. Canada Competition Bureau Approves Purolator Sale, ReUTERS Fin SERV., Nov. 26, 1993, available in LEXIS, News Library, Txtnws File.

133. COMPETITION AND REGULATION, supra note 26, at 24 n.6.

134. Richard Siklos, supra note 130, at 3.

135. Bureau of Competition Policy, Backgrounder: Canada Post Corp./Purolator COURIER INC. 1 (Nov. 26, 1993) [hereinafter BACKGROUNDER: CANADA POST CORP./PUROLATOR COURIER].

136. Federal Express-Competition Bureau Decision Inadequate, CAN. NEWSWIRE, Nov. 29, 1993, available in LEXIS, News Library, Curnws File. 
should compete with firms in the private sector [was] not within the purview of the Act, the purpose of which is to maintain and encourage competition in Canada."137 Thus the Bureau of Competition Policy properly limited the scope of its investigation to the reach of its existing jurisdiction under the Competition Act and did not assess broader questions of government policy.

Expert testimony supported opposing conclusions on the narrowly drawn issue of actual and potential cross-subsidization and predatory pricing. Professor Leonard Waverman of the University of Toronto argued that "the entire body of economic literature and specific material presented to the Bureau states that a monopolist like Canada Post has the incentive to crosssubsidize its competitive activities." ${ }^{138}$ Another University of Toronto economist, Professor Frank Mathewson, supported the position that "the available empirical evidence establishes that Canada Post has not engaged in improper cross-subsidization or predatory pricing activities." According to Mathewson, "the pricing mandate of Canada Post is not one of predation and does not involve or rely upon cross-subsidization of competitive products using revenues generated from Canada Post's exclusive privilege products or services."139

Only two cases in Canada have addressed the issue of predatory pricing under the Competition Act. ${ }^{140}$ As a result, the methodology outlined in the Bureau of Competition Policy's Predatory Pricing Enforcement Guidelines provides the authority for determining the existence of alleged predatory pricing as prohibited by the Competition Act. ${ }^{141}$ The Guidelines present a two-pronged analysis. The first part considers whether the alleged wrongdoer has the market power sufficient to lessen competition or eliminate competitors. ${ }^{142}$ Market share is considered a proxy for market power. It is presumed that a market share of less than $35 \%$ is unlikely to enable a company to price in a predatory manner and then recoup incurred losses by later charging supracompetitive prices in the absence of competitors. ${ }^{143}$ The second part of the Bureau's test scrutinizes the prices of the alleged predator to determine whether they are "unreasonably low."144 Price-cost margins are used to assess the reasonableness of prices. Prices at or above average total cost are not considered unreasonably low, regardless of market power possessed by the alleged predator. Prices below the average variable cost are usually considered unreasonably low. Prices set between average total cost

137. BACKGROUNDER: CANADA POST CORP./PUROLATOR, supra note 135 , at 1 .

138. Competition Bureau Decision Inadequate, supra note 136.

139. COMPETITION AND REGULATION, supra note 26, at 24-25.

140. Id. at 22 .

141. Id. at 23.

142. Id.

143. Id.

144. Id. 
and average variable cost are not considered predatory in the absence of direct or indirect evidence of predatory intent. ${ }^{145}$

Director Addy's examination focused on market share and concentration, barriers to entry, the effectiveness of remaining competition, and issues surrounding cross-subsidization. ${ }^{146}$ The Director judged the strength of the remaining competitors, as well as the nature and extent of both entry and expansion, as guards against potential cross-subsidization and predatory pricing. ${ }^{147} \mathrm{He}$ found that the combined revenues of Priority Courier and Purolator represented approximately $40 \%$ of revenues generated in the Canadian small parcel express market, and that the four largest firms in that market would receive approximately $70 \%$ of all revenues. ${ }^{148}$ Although the Director acknowledged that the cost of entering the small parcel express market on a national basis involves significant costs, he found that regulatory impediments to entry are moderate and that there are enough potential entrants that would enter the market in response to supracompetitive pricing. ${ }^{149}$ Furthermore, demand in the relevant market was particularly price sensitive, and competition was robust. ${ }^{150}$ The Director was convinced that its acquisition of Purolator would not give Canada Post the ability to sustain a significant and nontransitory price increase. ${ }^{151}$

\section{Limited Regulatory Oversight}

Canada Post is a largely autonomous and unregulated organization, particularly in light of the fact that it has a statutory monopoly over the delivery of letter mail. The government appoints the board of directors, the chairman of the board, and the president. ${ }^{152}$ The board is responsible for managing Canada Post. ${ }^{153}$ Subject to the approval of the Governor in Council, the board may prescribe its own regulations for operating the corporation. Among other terms, those regulations define what constitutes a "letter" and, thus, what material falls within the scope of Canada Post's statutory monopoly. ${ }^{154}$ As discussed earlier, Canada Post sets its own rates, almost entirely without government oversight. ${ }^{155}$ Canada Post must comply with directives issued by the Minister responsible for the corporation. ${ }^{156}$ However,

145. Id.

146. BACKGROUNDER: CANADA POST CORP./PUROLATOR COURIER, supra note 135 , at 3.

147. BUREAU OF COMPETITION POLICY, NeWS RElEASE: DiRECTOR WIL Not OPPOSE CaNADA POST ACQUISTION OF PUROLATOR (1993) [hereinafter BUREAU NEWS RELEASE].

148. BACKGROUNDER: CANADA POST CORP./PUROLATOR, supra note 135, at 4.

149. Id.

150. Id. at 6.

151. BUREAU NEWS RELEASE, supra note 147.

152. Canada Post Corporation Act, R.S.C., ch. C-10, \$§ 6-8 (1985) (Can.).

153. $\$ 10$.

154. \$ 19.

155. Id.; Price Waterhouse STRATEgic ReVIEW, supra note 14 , at 15.

156. Id. at 13; Canada Post Corporation Act, R.S.C., ch. C-10, § 22 (1985) (Can.). 
in practice, the Minister issues statements to the public regarding what changes in policy Canada Post ought to implement more often than he issues actual directives. ${ }^{157}$

Canada Post's board has significant autonomy in making its investment decisions and setting its own course. ${ }^{158}$ Although Canada Post may not invest in publicly traded companies, the corporation was able to structure its acquisition of Purolator to conform to relevant legal constraints. ${ }^{159}$

\section{Summary}

As a Crown corporation, Canada Post enjoys Parlimentary-bestowed privileges and immunities, such as a monopoly over lettermail. It also holds many direct and indirect subsidies, such as federal funding of its pension plan and favorable borrowing terms enjoyed by government entities in private capital markets. Nonetheless, the corporation finds itself confronting the daunting reality of eroding lettermail volumes due to the growth of such substitutes as courier delivery, electronic mail, and electronic funds transfers. In response, Canada Post is aggressively expanding into new markets where it competes with private firms.

Canada Post forayed into a dominant position within the courier service market with its purchase of Purolator. Currently, the corporation controls approximately $50 \%$ of that market. It also has become a significant player in the unaddressed admail delivery market by taking advantage of its de facto monopoly over access to locked mailboxes and mailboxes in apartment buildings. Canada Post's expansion has not been limited to the courier and admail markets. The corporation has positioned itself as a competitor in a variety of new communication markets, including e-mail, faxmail, desktop publishing, and electronic commerce.

In light of all the privileges and immunities that Canada Post enjoys, especially its statutory monopoly over lettermail, its expansion into new markets in competition with private firms raises a number of concerns. One key concern involves Canada Post's ability to exploit its monopoly power in lettermail to the detriment of its rivals in competitive markets. The exploitation may take the form of Canada Post cross-subsidizing the provision of its competitive services with revenue from its statutorily protected businesses. The concern with such cross-subsidization is heightened when one considers that Canada Post's ratemaking process lacks transparency, and no third-party regulatory agency is charged with overseeing the rates implemented by the corporation. Cross-subsidization becomes an even greater concern in light of the concessions accorded to Canada Post's

157. Price Waterhouse Strategic RevieW, supra note 14 , at 14.

158. Id. at 18 .

159. Id. 
èmployees. For example, its employees cannot be laid off. Such concessions seriously undermine Canada Post's ability to become a low-cost provider of postal services in competition with private firms, but for its ability to crosssubsidize.

\section{Technological Justifications for the Postal Monopoly}

There are two main technological justifications offered for the protection and extension of a government postal monopoly: (1) the presence of a natural monopoly production technology and (2) the existence of economies of scope. These arguments are used to imply that the monopoly over first class mail should be protected by statute and that Canada Post should expand into other markets to achieve cost efficiencies. But why should one presume the presence of a natural monopoly? The burden of proof should be on those asserting the existence of natural monopoly to show that it in fact exists. For if a natural monopoly can be shown for letter mail, it follows logically that the entire market for postal services would be best served by a single firm-an improbable proposition. ${ }^{160}$ Placing the burden of proof on the monopolists is especially appropriate if proponents of natural monopoly seek to preserve a statutory monopoly as well.

This Part of the Article shows that the natural monopoly justification for Canada Post's monopoly over letter mail has no basis in current technological and market developments in communications, transportation, and delivery services in Canada. There is, consequently, no reason to conclude that postal delivery is a natural monopoly or to continue or to extend the statutory monopoly on postal services. For similar reasons, the rationale based on economies of scope is also unpersuasive.

\section{A. The Natural Monopoly Justification for the Public Postal Monopoly}

The natural monopoly argument for public provision of postal services under a statutory monopoly has two components. First, the argument asserts that the provision of postal services is a natural monopoly. Second, the argument asserts that the cost savings from having a single provider of those

160. For proponents of the natural monopoly theory see Bruce M. Owen \& Robert D. Willig, Economics and Postal Pricing, in The FutURe OF THE POSTAL SERVICE 227, 236 (Joel L. Fleishman ed., 1983); John C. Panzar, Competition, Efficiency, and the Vertical Structure of Postal Services, in Regulation AND tHe NatuRe Of POSTAL Delivery SeRvices at 91, 94 (Michael A. Crew \& Paul R. Kleindorfer eds., 1992); John C. Panzar, The Economics of Mail Delivery, in GoverNING THE POSTAL. SERVICE 1, 1-3 (J. Gregory Sidak ed., 1994); John C. Panzar, Is the Postal Service a Natural Monopoly?, in COMPETITION AND INNOVATION IN POSTAL SERVICES, supra note 112, at 219, 222-24; Cathy M. Rogerson \& William M. Takis, Economies of Scale and Scope and Competition in Postal Services, in REgUlation AND THE NATURE OF POSTAL DELIVERY SERVICES, supra at 109, 113-15. See also Michael A. CREW \& PAUl R. Kleindorfer, THE ECONOMics Of Postal SER Vice 17-18 (1992). 
services can only be achieved by regulatory exclusion of private competitors. Both assertions are incorrect.

Given existing technology and market alternatives, Canada Post is far from being a natural monopoly. Technological arguments cannot justify barring entry into the market because competitive, privately-owned companies can realize the benefits of any increasing returns to scale that might inhere in the provision of postal services.

\section{B. The Definition of Natural Monopoly}

A production technology is said to exhibit the property of natural monopoly if a single firm can supply the market at lower cost than two or more firms can. ${ }^{161}$ This textbook definition of natural monopoly is based on a cost function that assigns total costs to outputs. The cost function has the natural monopoly property if a firm with that cost function has lower costs than would an allocation of output among two or more firms using the same cost function. If the technology of mail delivery exhibits natural monopoly characteristics, then a single firm can construct and operate that network at a lower cost than can two or more firms. Under those circumstances, the single firm is said to have subadditive costs.

The notion of natural monopoly is used to justify public ownership and control of Canada Post and its statutory monopoly over letter mail. According to that argument, regulation of entry is necessary to achieve static efficiency by establishing the least-cost industry structure-namely, a single firm.

One would expect under quite general conditions that competitive industries achieve the requisite cost efficiencies from consolidation of production, whether through expansion, mergers, or procurement contracts. It bears emphasis, however, that even if Canada Post were to have subadditive costs, its exclusive privilege over letter mail would not be necessary unless one could show that Canada Post is an unsustainable natural monopoly. The sustainability issue need not detain us. Even if there were cost efficiencies from natural monopoly, one would have to show that achieving those gains through a protected monopoly yielded benefits exceeding those from greater innovation, product variety, and lower administrative costs in a competitive market.

A number of elements of the definition of natural monopoly deserve emphasis because understanding all of their implications is necessary in order

161. See William J. Baumol et al., Contestable Markets and the Theory of INDUSTRY StRUCTURE 8 (1982); SANFORD V. BERG \& JOHN TSCHIRHART, NATURAL MONOPOlY REgUlation: PRINCIPLES AND PRACTICE 22 (1988); DENNIS W. CARLTON \& JEFFREY M. PERLOFF, MODERN INDUSTRIAL ORGANIZATION 295-96 (2d ed. 1994); ROGER SHERMAN, THE REGULATION OF MONOPOLY 80-81 (1989); DaNiel F. SPUlber, Regulation and MaRKeTs 3 (1989); JeAN TIROLE, THE THEORY OF INDUSTRIAL ORganization 19-20 (1988); KENNETH E. TRAIN, OPTIMAL REgUlation: THE ECONOMIC THEORY OF NATURAL MONOPOLY 6-8 (1991). 
to correctly apply the definition to mail delivery. The definition of natural monopoly begins with a known technology, as represented by the natural monopoly cost function. To assert that an industry is characterized by natural monopoly, one implicitly assumes that there is a single "best" technology that is commonly known, that all firms would have access to that technology, and that all firms operating the technology would be at the efficient productionpossibility frontier. ${ }^{162}$ In particular, the natural monopoly cost function is a long-run cost function, so that investment can be adjusted to achieve the efficient level of capital investment required for operating at minimum cost for each output level. In evaluating the applicability of the natural monopoly argument, we shall consider the extent to which those aspects of the definition of natural monopoly are indeed appropriate to Canada Post's system of collection, sortation, transportation, and distribution.

On the basis of the standard definition, a cost function for a given production technology has the natural monopoly property if the technology exhibits economies of scale over the relevant range of output. In particular, economies of scale are said to be present if the marginal cost of production is less than the average cost of production over the relevant range of output. ${ }^{163}$ Stated differently, economies of scale are said to exist over the relevant range of output when unit costs decline with the volume of production. Economies of scale are a sufficient condition for natural monopoly for a single-product firm.

Economies of scale can be due to many different technological factors. Fixed costs are a source of economies of scale, particularly in industries that require physical networks, such as telecommunications, railroads, oil and natural gas pipelines, electricity, and water services. Fixed costs are costs that do not vary with fluctuations in output, unlike operating or "variable" costs. The fixed costs of establishing a network system are the costs of facilities such as transmission lines, which are not sensitive to the level of transmission on the lines.

The need to avoid duplication of facilities, particularly duplication of the fixed costs of the network system, is an important component of the natural monopoly argument for regulation of mail delivery. The argument is that, because costs are minimized by not duplicating network infrastructure, regulators should bar the entry of competing carriers. That argument has been put forward in a wide range of regulated industries in which transmission or transportation facilities are a significant portion of total costs. The duplication argument, however, is inapplicable to mail delivery.

162. SPULBER, supra note 161 , at 138 .

163. Id. at 115-18; CARLTON \& PERLOFF, supra note 161, at 58-63. 


\section{Is Canada Post a Natural Monopoly?}

Canada Post is a wholesale and retail provider of delivery services. Those services involve three main components: (1) contracting for long-distance transportation, (2) regional sortation and transportation, and (3) local pick-up, sortation, and delivery. There is no reason to presume that the technologies for these components, whether taken singly or together, exhibit the properties of a natural monopoly.

\section{Contracting for Long-Distance Transportation}

Contracting for long-distance transportation is not a natural monopoly. Canada Post relies entirely on competitive providers of transportation, including airlines, trucks, ships, and railroads for long-distance transportation; it performs none of its own long-distance transportation. ${ }^{164}$ Canada Post also relies on those long-distance transportation companies with which it contracts to perform much of the information services associated with the transportation, such as tracking and trend analyses. In June 1995, Canada Post announced an agreement with Canadian National (CN), Canada's largest railway; shortly thereafter, $\mathrm{CN}$ Intermodal carried one-eighth of Canada Post's long-haul (greater than 350 miles) container traffic nationwide, and as much as one-fourth in major corridors such as Montreal/Toronto to western Canada ${ }^{165}$ Also under the agreement, CN's Intermodal Logistics Centre will "allocate equipment and train capacity [to Canada Post], and provide personalized service and status updates to [Canada Post] on a seven-day/24hour basis." 166 In the words of one $\mathrm{CN}$ employee: "We monitor our own performance to ensure that Canada Post shipments are on schedule."167

Clearly, contracting for such transportation does not exhibit natural monopoly properties. Any customer of those transportation firms is equally capable of procuring such services.

Canada Post depends on the ability of competitive transportation firms to provide information support to facilitate package exchange. Important developments in electronic data interchange and computerized reservation systems have drastically improved the efficiency of freight transportation. Those efficiencies are widely exploited by private companies and extend easily to transportation of mail, packages, and freight containers currently handled by the postal system. In fact, Canada Post's chief executive officer has said that it is more efficient for Canada Post to rely on publicly available

164. Clermont Testimony, supra note 52.

165. Canadian National Earns Canada Post "Stamp of Approval," CAN. NEWsWIRE, June 28, 1995, available in LEXIS, News Library, Curnws File.

166. Id.

167. Id. 
information technology: "[W]e found out that our information technology staff tended to re-invent what was already out in the market."168

\section{Regional Sortation and Transportation}

Regional sortation and transportation also are not natural monopolies. Transportation by truck does not exhibit any natural monopoly properties. Although there may be organizational economies in coordinating and operating transportation systems, regional transportation can be provided by multiple carriers. Certainly no one would suggest that a region is best served by a single trucking company.

Regional sortation is not a natural monopoly either. Although there may be substantial economies of scale at the level of the individual sorting plant, this does not imply that a single company should operate all of the sorting plants across the country, or even within a region. The technology and distribution of regional sortation differs little from warehousing by wholesalers or retail chains for general merchandise, such as Safeway or WalMart. No one would seriously suggest that wholesale supply of general merchandise be provided by a single company. In short, the notion that regional sortation and delivery have natural monopoly properties is not defensible.

\section{Local Collection, Sortation, and Delivery}

If there is no naturally monopolistic production technology for regional sortation and transportation or for long-distance transportation, then Canada Post can be a natural monopoly only if local collection, sortation, and delivery exhibit characteristics of natural monopoly and do so in sufficient magnitude to dominate the constant or decreasing returns to scale found in regional sortation and transportation and in long-distance transportation. ${ }^{169}$ Several economists have argued that economies of scale exist in the local delivery of mail. ${ }^{170}$ As we shall see, however, such economies are limited in nature and do not suggest the need for entry restrictions into letter mail or government control of Canada Post. Even the existence of such economies would not be sufficient evidence from which to conclude that a single firm should control all local service throughout Canada. At most, such economies would imply that each locality should have a single service provider. ${ }^{171}$

168. Clermont Testimony, supra note 52.

169. See George J. Stigler, The Division of Labor Is Limited by the Extent of the Market, $59 \mathrm{~J}$. POL. ECON. 185 (1951), reprinted in GEORGE J. STIGLER, THE ORGANIZATION OF INDUSTRY 129 (1968).

170. See sources cited supra note 160.

171. Sharon Oster has proposed that the U.S. Postal Service be divided into regional firms akin to the seven regional Bell operating companies formed by the AT\&T breakup. Sharon M. Oster, The Postal Service as a Public Enterprise, in GOVERNING THE POSTAL SERVICE, supra note 160, at 31. 
Moreover, the existence of local economies of scale would not justify unified control of the other two components of Canada Post-regional sortation and transportation, and contracting for long-distance transportation. Even if there were vertical economies from combining local service with regional sortation and delivery, that condition would not justify horizontal integration across all localities; rather, it would support the creation of multiple vertical networks. Such a development would be roughly analogous to the growth of competing full-service networks in telecommunications. ${ }^{172}$

Network externalities are said to exist if adding more customers or points of access to a network increases benefits or lowers costs to the existing customers of the network. Thus, telephone subscribers benefit from companies' hooking up additional customers because they can reach or be reached by more people. Even if network economies are present, that need not imply that there should be only one network operator and owner. Networking benefits can be achieved by interconnecting multiple networks. Moreover, portions of any given network can be owned and operated independently, with interconnections achieved through contracts. The analogy between postal networks and telecommunications, rail, and electric power networks is a tenuous one in any case. The local postal network bears little resemblance to those networks, because there are no location-specific transmission or rail lines that require substantial capital investment. The postal routes covered by persons can be duplicated with relatively low capital expenditures.

The postal network may exhibit coordination economies in a particular form, as evidenced by the use of hub-and-spoke systems by competing private carriers. Such a pattern does not imply that only one network should operate, nor does it suggest that the government must own and operate such a network. Moreover, the coordination problems differ little from those of any transportation or wholesale company that must sort and route packages from one address to another. Those are routine functions that are effectively performed by private companies. The coordination problems required for reliability by telecommunications or electricity networks are much more complex, require far more rapid responses, and have more severe consequences. Yet, even in those types of networks, coordination is achieved through contractual agreements and cooperation councils extending across individual companies.

Local service has three components: inward sortation by postal carriers, door-to-door delivery by postal carriers in trucks and on foot, and collection of mail at mailboxes and post offices. Those three elements involve wellunderstood, traditional technology. Economies of scale in those activities are

172. See, e.g., WILliam J. BAUMOL \& J. GREgORY SidAK, TOWARD COMPETITION IN LOCAL TELEPHONY 10-19 (1994); J. Gregory Sidak, Telecommunications in Jericho, 81 CAL. L. REV. 1209, 1223-27 (1993) (book review). 
minimal. The productive inputs involved, primarily labor services and vehicles, can be "smoothly" adjusted to reflect the volume of mail.

\section{a. Inward Sortation}

The inward sortation function can be split among multiple firms without a loss in efficiency. Just as inward sortation is split across postal employees, it can be split across companies. Indeed, larger mailers perform a degree of inward sortation to qualify for presort discounts. ${ }^{173}$ In fact, Canada Post has encouraged discounts for bulk mailers who presort to reflect customer capabilities and reduce Canada Post's costs. ${ }^{174}$ There are no apparent economies of scale of any significance for inward sortation.

\section{b. Door-to-Door Delivery}

The traditional natural monopoly argument emphasizes door-to-door delivery by postal carriers in trucks and on foot. In 1848, John Stuart Mill suggested the need to avoid duplication of effort by pedestrian postmen serving a given street in London:

As a general rule, the expenses of a business do not increase by any means proportionally to the quantity of business. Let us take as an example, a set of operations which we are accustomed to see carried on by one great establishment, that of the Post Office. Suppose that the business, let us say only of the London letter-post, instead of being centralized in a single concern, were divided among five or six competing companies. Each of these would be obliged to maintain almost as large an establishment as is now sufficient for the whole. Since each must arrange for receiving and delivering letters in all parts of the town, each must send letter-carriers into every street, and almost every alley, and this too as many times in the day as is now done by the Post Office, if the service is to be as well performed. Each must have an office for receiving letters in every neighborhood, with all subsidiary arrangements for collecting the letters from the different offices and re-distributing them. I say nothing of the much greater number of superior officers who would be required to check and control the subordinates, implying not only a greater cost in salaries for such responsible officers, but the necessity, perhaps, of being satisfied in many instances with an inferior standard of qualification, and so failing in the object. ${ }^{175}$

173. PRICE Waterhouse Strategic RevieW, supra note 14, at 15.

174. Id.

175. 1 John StUART MLL, PRINCIPLES Of POLITICAL ECONOMY $164-65$ (2d ed. 1848). 
Those economies of scale may have existed 150 years ago in London, but it is far from obvious today that any appreciable economies of scale obtain with the higher mail volumes and population densities in Canadian cities and suburbs.

Certainly the volumetric limits of a mail truck, as well as the weight and volumetric limits of a mail carrier's bag, imply decreasing returns to scale when the quantity of mail being delivered to a neighborhood reaches a certain level. Even in rural areas, where population density may be low, modern transportation vehicles allow deliveries over a wider area. Even if there are cost savings from having a single delivery provider for rural areas, that condition need not preclude private provision of such service. Even rural areas may be served by multiple newspaper delivery routes, which demonstrates that an extremely low-cost service can be maintained simply for the delivery of one item on a daily basis to a substantial proportion of households. In short, nothing inherent in the technology of truck driving and walking justifies government ownership and control of Canada Post or a monopoly in the delivery of letter mail.

A second alleged economy of scale in door-to-door delivery arises because the cost of making a delivery to a particular location does not depend on the number of pieces delivered there. That relationship means that Canada Post can lower the average cost of delivering letters to a particular location by increasing the number of pieces delivered. That cost condition does not necessarily imply that only one delivery service should exist, for the rate at which average costs fall depends on the chosen frequency of delivery. A reduction in the frequency of delivery increases the likelihood that multiple pieces will be delivered to a given household and thus reduces the average cost of delivery. Households may differ in their frequency requirements so that not all require daily delivery. Multiple delivery services can provide services of varying quality at lower cost.

Furthermore, to the extent that Canada Post can achieve economies of scale in delivery, they may reflect an absence of any effective oversight of Canada Post's discretion to set standards for quality of service. ${ }^{176}$ Canada Post can influence the extent of economies of scale in delivery by the level of quality it sets-such as the number of deliveries per day or week, the average number of days necessary to deliver a letter, and so forth. Economies of scale in delivery (that is, the probability that there will be two or more pieces for delivery to a single mail stop on a given delivery run) increase as delivery becomes less frequent, the mail stream moves more slowly, the volume of non-time-sensitive mail rises, and non-time-sensitive mail is priced at lower levels that reflect a smaller allocation of common fixed costs. Thus, to the

176. See J. Gregory Sidak, The Economics of Mail Delivery: Commentary, in GoVERNING THE POSTAL SER VICE, supra note 160 , at 14, 14-15. 
extent that Canada Post's intellectual defense for the continuation of the statutory monopoly over letter mail is predicated on the existence of scale economies in delivery, Canada Post can increase the magnitude of those economies - though at a cost to consumers-by attributing as few costs as possible to other classes of mail.

Stated differently, if the frequency of delivery were market driven, Canada Post's alleged economies of scale would vanish. We do not observe, for example, "natural monopoly" delivery services in each metropolitan or rural area that act as common carriers for delivering pizza, appliances, furniture, or nursery products. Why not? Because any gains from exploiting economies of scale are more than offset by other aspects of service quality that derive from controlling one's own delivery network.

A third potential reason of economies of scale in door-to-door delivery is that, increasingly, a postman does not really go all the way to the customer's door. The delivery of mail in new suburban neighborhoods, for example, is typically to a group of boxes that may be seventy-five feet or more from the customer's home. Canada Post has increasingly replaced door-step service with delivery to such community or cluster mailboxes. ${ }^{177}$ The customer then, in effect, completes the last leg of the delivery. He cannot pay Canada Post to deliver to his door; that is, consumers cannot buy higher-quality mail service from Canada Post the way they can buy higher-quality services from private suppliers of goods and services. This truncation of services offered by Canada Post directly relates to the perception of economies of scale in delivery. Aggregated mailboxes in newer neighborhoods, for example, reduce the cost of delivery for Canada Post but impose a delivery cost on mail recipients, who must walk from their homes to get their mail. That cost will vary from consumer to consumer and could be considerable for some, such as an older person forced to walk in snowy, rainy, or icy conditions to her mailbox. Thus, the economies of scale that some claim to exist over the delivery function may come at greater private cost to consumers. If so, they are false economies indeed. ${ }^{178}$

177. CANADA POST ANNUAL REPORT, supra note 17, at 23

178. See J. Gregory Sidak, The Economics of Mail Delivery: Commentary, in GovERNING THE POSTAL SERVICE, supra note 160, at 15-16. In remarks concerning the U.S. Postal Service, Judge Douglas Ginsburg, who was formerly Assistant Attomey General for Antitrust, has noted that a consumer

cannot buy door-to-door service because, under the postal regulation, the mail goes only to the street ... . [Further], there is only daily service, and increasingly less of it. You cannot sign up for twice-daily service. And you cannot say, "I'll pay less to receive twice-weekly service," because you do not pay on the receiving end. This high degree of uniformity and standardization that has become normal in the Postal Service--even the postal box has to conform to postal regulations-is emblematic of the potential loss in consumer satisfaction, consumer surplus, and consumer welfare that we associate with the old integrated telephone system.

The Economics of Mail Delivery: Discussion, in GOVERNING THE POSTAL SERVICE, supra note I60, at 19 (remarks of Douglas H. Ginsburg). 


\section{c. Collection of Mail}

Just as with long-distance transportation and inward sortation, Canada Post itself has demonstrated that collection of mail at its retail access points cannot be considered to have natural monopoly characteristics. Canada Post distributes its services through nearly 18,500 retail access points. ${ }^{179}$ Private businesses operate approximately $75 \%$ of those retail outlets. ${ }^{180}$ Furthermore, there is nothing inherent in government ownership and control over retail locations and the equipment used to provide local distribution service that would suggest the presence of cost savings from unified ownership and control. That Canada Post recognizes that fact is evidenced by its initiative to lease operating equipment to enhance operational flexibility and reduce spending. ${ }^{181}$ Canada Post also contracts out its property management function because, according to its chief executive officer, "we are not managers of real estate-and this result[s] in huge savings." ${ }^{182}$

\section{Summary and Implications}

None of the components of postal service-contracting for long-distance transportation, regional sortation and transportation, or local collection, sortation, and delivery-exhibits the natural monopoly property. That conclusion comports with Mr. Clermont's observation that "[m]ost of our 'non-core' operations are contracted out." 183 Canada Post's continued statutory monopoly over letter mail therefore cannot rest on the assertion that it reaps the benefits of a natural monopoly technology for Canadian consumers. There are, consequently, no cost-efficiency grounds for restricting entry or preventing competition in Canadian postal markets.

\section{The Fallacy That Canada Post Must Be a Nationwide Full-Service Carrier}

Economies of scope are used to justify preserving a multiproduct natural monopoly for Canada Post. Moreover, the possibility of achieving additional economies of scope by expansion into new markets is used to argue for extension of the postal monopoly. Canada Post seeks to increase its presence in parcel post, express mail, and other services because it is asserted that there are increasing returns to producing those services jointly with letter mail. The

\footnotetext{
179. CANAda POST CORPORATE PLAN, supra note 8, at 2.

180. Price Waterhouse Strategic RevieW, supra note 14, at 13.

181. CANADA POST ANNUAL REPORT, supra note 17 , at 23

182. Clermont Testimony, supra note 52.

183. Id.
} 
reasoning seems to be that any additional contribution to overhead, no matter how small, justifies a new line of business.

A firm's technology is said to exhibit economies of scope if a single firm can produce two products at a lower cost than if each product were produced by a different firm. ${ }^{184}$ The cost of producing one of the products alone is its stand-alone cost. ${ }^{185}$ Economies of scope are said to exist if the sum of the stand-alone costs of the two products exceeds the cost of joint production. In the multiproduct case, a production technology is said to have the natural monopoly property if a single firm can provide the bundle of products (such as cars and trucks, or the delivery of letters and parcels) at a lower cost than can two or more firms.

Economies of scope often stem from sharing joint and common costs across a range of services. That sharing might take the form of common overhead costs for the production of multiple products or services. The use of hub-and-spoke systems in network industries creates economies of scope if the usage density is higher on each branch in comparison with a point-topoint system. The sharing of trunk lines to connect multiple branches in a network creates economies of scope in comparison with stand-alone systems that duplicate the trunk-line facility.

An assessment of economies of scope depends on how the firm's products or services are defined. Products can be delineated arbitrarily on the basis of product features, customer characteristics, location, time available, brand names, and so on. Postal services such as standard letter mail, parcel post, and express mail represent arbitrary historical classifications based largely on the content of the mail. Those services can share overhead depending on how the postal delivery service is organized.

Yet, for the same reasons that it is implausible that the production technology for postal delivery exhibits the natural monopoly property, it is also implausible that there are substantial economies of scope in postal delivery. Because transportation is contracted out to independent carriers, Canada Post cannot be said to realize any economies of scope at this stage; the fact that multiple independent providers actually perform the transportation services negates any economies of scope resulting from a single service provider. Regional sortation and delivery can exhibit economies of scope only to the extent that two types of mail are routed through the same facilities. Local delivery can exhibit some economies of scope again to the extent that, say, first and third class mail are sorted and delivered together, but not if the services are provided independently.

184. An early exposition of economies of scope is John C. Panzar \& Robert D. Willig, Economies of Scale in Multi-Output Production, 91 Q.J. ECON. 481 (1977). For subsequent discussions, see SPULBER, supra note 161, at 114-17.

185. See, e.g., BAUMOL \& SIDAK, supra note 172, at 58-59. 
In any case, the presence of economies of scope is not sufficient to justify the postal monopoly. Multiple carriers can each achieve economies of scope if each offers multiple services. United Parcel Service, for example, offers delivery for both overnight mail and parcels.

Moreover, economies of scope do not justify extending the postal monopoly. On the contrary, the presence of economies of scope would more plausibly imply the need to eliminate the postal monopoly. There are currently private carriers of express mail-such as Federal Express and United Parcel Service, to name only two-that are not permitted to carry standard letter mail. If there are economies of scope between standard letter mail and express mail service, those private carriers could realize those economies if Canada Post did not have an exclusive privilege over standard letter mail. Thus, potential economies of scope do not imply any need to extend the government's postal monopoly. Rather, they imply the need to extend the range of permissible privately supplied services.

A private firm considering entry into a market will determine whether its stand-alone cost for a given product would be less than the prevailing price for that product in that market. ${ }^{186}$ Of course, the prospective entrant is free to enter by simultaneously offering two or more products over which it can achieve economies of scope. For example, because an alternative advertising carrier already provides service to a neighborhood, the carrier's cost of entering the business of delivering letters no longer would be the stand-alone cost of letter delivery; rather, the cost of entry would be the incremental cost of adding letter delivery given that the carrier already delivers unaddressed advertising. Stated differently, the cost to the alternative advertising carrier of entering the letter delivery business would be the stand-alone cost of letter delivery minus the economies of scope (on a unit basis) derivable from the firm's joint delivery of unaddressed advertising and letter mail.

The same analysis of the incremental cost of entry would apply to the multiproduct activities of Canada Post were it not for the fact that the firm is a publicly owned and controlled enterprise. Canada Post offers many different services. If competition exists for all but the provision of letter mail, it is unnecessary for Canada Post to offer its letter mail service in conjunction with one or more of the other services even if Canada Post could achieve economies of scope by providing them jointly with the one noncompetitive class of mail. To conclude otherwise is to succumb to the fallacy that Canada Post must be a nationwide full-service carrier of all varieties of mail. To the contrary, the proper scope of market entry by a government-owned firm should be defined by the scope of the market failure that this form of government intervention seeks to redress, not by the cost-minimizing scope of a public firm that produces both competitive and noncompetitive products. Indeed, if significant economies of scope exist between competitive and non-

186. Id. at $77-78$. 
competitive products, then the more natural question to ask is why the superior regime is not private provision of all the products, subject perhaps to the usual price regulation, safeguards, cost allocation, and nondiscrimination requirements in the sale of access to bottleneck facilities, and so forth.

In its most recent corporate plan, Canada Post expresses its belief that "[i]ncreasingly, customers are looking for a single distributor to handle their needs in an increasingly borderless market." ${ }^{187}$ What drives Canada Post in its expansionist movement is its conviction that to remain a viable economic entity, it must be a nationwide full-service provider of communication, transportation, and delivery services. That assumption, however, has no basis in economic theory. If competition is feasible in a particular class of mail, as the evidence in parcel post and overnight mail amply demonstrates, then there is no market failure necessitating government involvement in the first place. There is a fortiori no need for the government itself to provide such service and thereby to compete against private firms.

The same reasoning applies to the geographic scope of coverage for a particular service that private firms are capable of providing: There is no need for Canada Post to provide that service in locales where private firms can profitably provide it. It is doubtful, for example, that any postal service in Toronto or Montreal must be provided by a public enterprise. As a practical matter, of course, the geographic scope of private services is not an issue of controversy, because firms like United Parcel Service, Federal Express, and even Canada Post's Purolator Courier provide service throughout Canada.

Economic analysis offers no rationale why Canada Post should have to provide consumers every type of mail service or provide any particular type of service to consumers in all regions of the country. Sound public policy dictates that a government-owned entity should produce only those postal services which some form of market failure prevents private firms from profitably providing to consumers. The practical implication of that principle is that Canada Post should aspire to do less by exiting any market that is demonstrably competitive.

\section{E. Recapitulation}

Canada Post is not a natural monopoly. In contracting for long-distance transportation, in regional sortation and transportation, and in local collection, sortation, and delivery, the assertion that Canada Post is a natural monopoly is implausible as a matter of economic analysis. If anything, economic analysis suggests that Canada Post has considerable incentive and latitude to truncate consumer choices so as to increase the false appearance that economies of scale and scope exist in local delivery. There is no intellectually

187. CANADA POST CORPORATE Plan, supra noté 8 , at 8 . 
defensible argument that Canada Post's statutory monopoly flows directly from a natural monopoly that it purports to possess over mail delivery.

To the contrary, if economies of scope exist between letter mail and other classes of mail, that fact would strongly support elimination of Canada Post's exclusive privilege rather than expansion of the enterprise into competitive lines of business. Sound public policy should encourage the entry of private firms into mail services currently monopolized by the Canadian government rather than extend the government's monopoly into markets that private firms have already proven to be competitive.

\section{Public Provision of Postal Services}

It is not necessary for the government to provide the full range of postal services that consumers demand. Continued public provision of postal services runs counter to the movement toward privatization in numerous industries in many countries throughout the world, including Canada. ${ }^{188}$ The following analysis shows that public provision of postal services in Canada cannot be justified on the basis of market failure. It is apparent that competitive private firms effectively provide a wide variety of communication, transportation, and delivery services. The elimination of government restrictions on entry into postal services would lead to a significant increase in privately provided services.

The two principal reasons given today for public provision of postal services are the social goal of providing universal service, and the need to ensure the security of the mail stream. In an era long since passed, the postal service was admittedly an essential component of a nation's infrastructure. ${ }^{189}$ Canada Post's chief executive officer still embraces that view: "Postal administrations are mandated to serve the whole country, however remote the area. It is one of those intangible things that forms a nation."190 That statement had greater validity when the only two means of communication were face-to-face conversation and transportation of written words, but times have changed drastically. Those historical justifications need not detain our current analysis, for technological change and market developments now provide many alternative means of communication that have long since eliminated the need to rely on a national postal service to achieve those objectives. Indeed, the elimination of those outdated justifications reveals

188. See George L. Priest, Socialism, Eastern Europe, and the Question of the Postal Monopoly, in GOVERNING THE POSTAL SERVICE, supra note 160, at 46. For a discussion of the extensive privatization initiatives in the United Kingdom, see JOHN VICKERS \& GEORGE YARROW, PRIVATIZATION: AN ECONOMIC ANALYSIS (1988). For a discussion of privatization of postal services, see Michael A. Crew \& Paul R. Kleindorfer, Pricing, Entry, Service Quality, and Innovation under a Commercialized Postal Service, in GOVERNING THE POSTAL SERVICE. supra note 160, at 151-57.

189. See Ruth LaPham BUTLER, Doctor FrankLin POSTMASTER GeNERAL (1928).

190. Clermont Testimony, supra note 52. 
how intellectually flimsy is the case for continued public provision of postal services.

The two contemporary justifications for public provision of postal services are inconsistent with current technological and market developments in communications, transportation, and delivery services in Canada. There is, consequently, no reason to continue public provision of the full range of postal services. Postal delivery has no insurmountable technological barriers to entry, and, indeed, extensive competitive provision of postal services already occurs. Further, postal services need not be publicly provided either to ensure ubiquity of service and pricing uniformity or to ensure the integrity of the mail stream.

\section{A. The Absence of Insurmountable Technological Barriers to Entry in Postal Delivery}

There do not appear to be any insurmountable technological barriers to entry in postal delivery. An economic entry barrier is a cost that must be borme by an entrant but not by an incumbent. ${ }^{191}$ The main barrier to entry that raises concerns in a regulated market is the problem of sunk costs. An incumbent firm can write off its irreversible costs of capital and thus only need be concerned about its variable costs in setting its prices. In contrast, an entrant not only must recover variable costs, but also must earn revenues that cover its irreversible entry costs. Sunk costs are a concern in network industries such as electricity and natural gas because the costs of transmission facilities are irreversible and transaction-specific. ${ }^{192}$

The postal system is often referred to as a network industry because any transportation and delivery system has many of the features of a network, particularly in terms of dispersed collection and delivery and of centralized sorting. ${ }^{193}$ That analogy does not, however, imply that the capital equipment of a postal delivery system is in any way comparable to that of a transmission network composed of pipelines or electric lines. To the contrary, equipment for the postal system is far from being an irreversible investment and is certainly not transaction-specific.

Canada Post's capital consists of buildings, vehicles, and sorting equipment. The buildings, which often are leased rather than owned, can be put to

191. SPULBER, supra note 161, at 40-41; GEORGE J. STIGLER, THE ORGANIZATION OF INDUSTRY 67 (1968); William J. Baumol \& Robert D. Willig, Fixed Costs, Sunk Costs, Entry Barriers and Sustainability of Monopoly, 96 Q.J. ECON. 405, 418 (1981).

192. As Paul Milgrom and John Roberts note, "the specificity of an asset is measured as the percentage of investment value that is lost when the asset is used outside the specific setting or relationship." PAUL MLgROM \& JOHN ROBERTS, ECONOMICS, ORGANIZATION AND MANAGEMENT 135 (1992) (emphasis in original). Both fixed and variable costs may have components that are transactionspecific and, thus, nonsalvageable. See OLIVER E. WILLIAMSON, THE ECONOMIC INSTITUTIONS OF CAPITALISM 52-56 (1985).

193. See sources cited supra note $\mathbf{I} 60$. 
other uses and are not tied to any particular customer location. ${ }^{194}$ Vehicles are obviously mobile assets. The services of sorting equipment, while specialized, are not tied to a particular customer, for they can be transferred across markets simply by transporting the items to be sorted to and from different locations. Those assets, such as sorting equipment and vehicles, have relatively short economic lives-unlike transmission facilities in such network industries as natural gas, electric power, and long-distance telecommunication-and thus do not represent an insurmountable barrier to entry. Therefore, sunk costs are not large in the postal services industry.

Furthermore, competitive entry into delivery services already has occurred. Indeed, for express service and parcels, Purolator (before Canada Post purchased a majority interest) and United Parcel Service already have established prominent positions in increasingly large markets. Actual competitive entry demonstrates conclusively that entry barriers are not an issue.

Many package delivery services operating in North America have made substantial investments in delivery. Companies in package delivery include Air Express International, Airborne Freight, American Freightways, Consolidated Freightways, DHL Worldwide Express, Greyhound Lines, Inc., Roadway Services, Inc., and United Parcel Service; express carriers include Federal Express, United Parcel Service, Airborne Freight, and Emery/Purolator, Loomis Courier Service, and Canpar Transport Ltd. ${ }^{195}$ In Canada alone, there are currently well over 2,000 companies competing in the small parcel express market. ${ }^{196}$ The rapid rate of growth and economic success of those firms show that the cost of investment is not preventing competitive entry into postal delivery. The same holds in the United States for the growth and planned expansion of second and third class mail delivery companies, such as Alternate Postal Delivery, Inc. (formerly United Delivery Systems, Inc.), ${ }^{197}$ and Time Warner's Publishers Express, Inc. ${ }^{198}$ The technology of those delivery services can be adapted to other types of mail, including letter mail. In short, private firms clearly are capable of providing postal services.

194. See Clermont Testimony, supra note 52.

195. See, e.g., AIRBORNE FreIGHT CORP., 1994 SEC FORM 10-K, at 3 (1995); AMERICAN FREIGHTWAYS CORP,, 1994 SEC FORM 10-K, at 3 (1995); CONSOLIDATED FREIGHTWAYS, INC., 1994 SEC FORM 10-K, at 3-5 (1995); CORPORATE PROFILE FOR DHL WORLDWIDE EXPRESS, BUS. WIRE, INC. (Sept. 9, 1994); FEDERAL EXPRESS CORP., 1994 SEC FORM 10-K, at 1 (1994); GREYHOUND LINES, INC., 1994 SEC FORM 10-K, at 3 (1995); ROADWAY SERVICES, INC., 1994 SEC FORM 10-K, at 1-5 (1995); BACKGROUNDER: CANADA POST CORPORATION/PUROLATOR COURIER INC., supra note 135, at 5.

196. BACKGROUNDER: CANADA POST CORP./PUROLATOR COURIER, supra note 135, at 6.

197. Alternate Postal Delivery, InC., SEC Form S-1 Registration Statement for INITLAL PUBLIC OFFERING OF $1,000,000$ SHARES OF COMMON STOCK (Aug. 2, 1995).

198. TIME WARNER INC., 1994 SEC FORM 10-K, at I-8 (1995). 


\section{B. Cost Economies Do Not Justify Public Provision of Postal Services}

Although mail delivery is clearly not a natural monopoly for the reasons explained in Part $\Pi$, any cost economies, if they did exist, still would not justify public provision of the full range of postal services by Canada Post. First, public ownership of an enterprise often implies that incentives for productive efficiency and cost minimization are absent. Second, private ownership of the facilities does not in any way impair the efficient operation of those facilities.

The possibility that technological cost economies may be present does not guarantee that they will be achieved. In his landmark study of economies of scale and scope, the business historian Alfred D. Chandler observes that managerial skill is required to attain those economies that are technologically available. ${ }^{199}$ Private owners have an incentive to maximize profits because they are the residual claimants to the returns on their investment. That state of affairs gives private owners an incentive to engage in oversight of managerial performance to guarantee that productive efficiency is achieved and that costs are minimized. Owners will likely provide managers with incentives for cost minimization. Canada Post has the option to issue shares to its employees, but it has not done so and gives no indication that it will issue any shares to any employees until 1999. ${ }^{200}$ Thus, under Canada Post's present government ownership, incentives for profit maximization are likely to be subordinate to political considerations.

Public ownership eliminates or severely reduces monitoring and oversight incentives. As a consequence, public ownership and control reduce incentives for cost minimization. For example, Canada Post has invested heavily in automation but has failed to achieve technical efficiencies. In 1994, Canada Post invested $\$ 208$ million in capital assets, and, in 1995 , it invested an additional $\$ 132$ million. ${ }^{201}$ Since Canada Post operates fewer than 4,600 of its own retail outlets and contracts out much of its transportation services, most of that investment is presumably in automated equipment. ${ }^{202}$ During that same period, however, total employment (measured in millions of hours paid) increased by more than $5 \% .{ }^{203}$ The U.S. Postal Service has demonstrated the same inability to achieve cost savings through investment in automation. ${ }^{204}$ In February 1995, the U.S. General Accounting Office (GAO) concluded: "The

199. Alfred D. Chandler, SCale and Scope: The DYNamics of Industrial Capitalism 17 (1990). See also Daniel F. Spulber, Economic Analysis and Management Strategy: A Survey Continued, 3 J. ECON. \& MGMT. STRATEGY 355, 378 (1994).

200. CANADA POST CORPORATE Plan, supra note 8, at 13.

201. CANADA POST ANNUAL REPORT, supra note 17, at 25.

202. See PRICE WATERHOUSE STRATEgIC ReVIEW, supra note 14; Clermont Testimony, supra note 52 .

203. Canada Post ANNUAl Report, supra note 17, at 36.

204. U.S. General ACCOUNTING OfFice, Postal Service: automation Is Taking Longer AND PRODUCING LESS THAN EXPECTED 2 (1995). 
savings from automation continue to be small compared to overall labor costs and more difficult to achieve than the Service anticipated."205 Similarly, Professors Paul MacAvoy and George McIsaac found that the Postal Service's automation program, the largest capitalization plan in any public sector service organization in the 1980s and 1990s, caused the Postal Service to have significantly higher capital costs but not significantly lower labor costs. ${ }^{206}$

Private ownership of the facilities used to deliver mail certainly would not prevent a company from achieving cost economies. Moreover, economic analysis shows that the presence of competitive firms leads to economies of scale in a market, for the pressure of potential competition from new entrants encourages pricing and cost discipline to incumbent firms. That incentive means that competitive firms would realize the technologically available economies of scale. Moreover, economic analysis shows that the existence of economies of scale in a market is consistent with the presence of competitive firms, for the pressure of potential competition from new entrants provides pricing and cost discipline to incumbent firms. Thus, the natural monopoly argument is not a sufficient condition for barring entry into the market for letter mail because competitive, privately owned companies can realize the benefits of any increasing returns to scale that they might obtain.

\section{Public Provision Is Not Needed to Ensure Ubiquity and Pricing Uniformity}

Perhaps the most popular argument for public ownership and control of Canada Post is to ensure reliable postal service throughout the country with the same quality of service for communities of similar size, as required by the Canada Post Corporation Act. ${ }^{207}$ The shorthand for that objective is "universal service." Unlike the U.S. Postal Service, which by statute must price its service uniformly throughout the country, Canada Post is not required by its postal statutes to provide universal service at uniform rates; nonetheless, Canada Post provides letter mail at a uniform rate, currently $45 \notin .^{208}$ The legislation requires only that Canada Post provide "a basic customary postal service at fair and reasonable rates" and that it maintain "a standard of service that will meet the needs of the people of Canada and that is similar with respect to communities of the same size." 209 Nevertheless, Canada Post has maintained that its "central public policy function" is "to

205. Id.

206. Paul w. macavoy \& George S. Mcisaac, The Current file on the Case for Privatization of the Federal Government Enterprises 121 (Hume Papers on Pub. Pol'y, No.3, 1995).

207. Canada Post Corporation Act, R.S.C., ch. C-10, § 5 (1985) (Can.).

208. PRICE WATERHOUSE STRATEGIC REVIEW, supra note 14 , at 14.

209. MANDATE REVIEW, supra note 2, at 66. 
provide universal letter service at affordable, uniform rates."210 The Review concurs with Canada Post's position. ${ }^{211}$

Canada Post views universal service as the justification not only for retaining its existing monopoly over letter mail, but also for expanding its operations in competitive markets. With the decrease in standard letter mail volume and the increase in costs (particularly labor costs), Canada Post recognizes that its continued existence depends on growth from other lines of business. "Confronted with the reality of increasingly aggressive competition, higher service expectations from customers, and an explosion of new communication technologies," notes Mr. Clermont, Canada Post's key objective is to become "our customers' supplier of choice." 212 Presumably referring to a perceived need to become a vertically integrated full-service provider of communication, transportation, and delivery services, $\mathrm{Mr}$. Clermont reveals Canada Post's concern over becoming irrelevant in the face of the proliferation of cheaper alternatives to letter mail. ${ }^{213}$ Canada Póst's corporate plan states that for its continued prosperity " $[\mathrm{t}]$ he Corporation must develop a new direction to improve profitability and improve the business."214 That "new direction" involves Canada Post's redefinition of its universal service mandate to justify the firm's entry into emerging information markets: "Just as [Canada Post] has made universal, affordable and reliable delivery of mail possible for all Canadians and businesses, it has a role to play in ensuring universality of service in an electronic industry that may not otherwise emerge on an equal access basis." ${ }^{215}$ The difficulty of defining and funding a universal service policy for interactive broadband networks suggests that the expanded role that Canada Post envisions for itself could result in a serious misallocation of public and private resources. ${ }^{216}$

A postal monopoly may also tend to exaggerate the importance of its universal service function to elevate the apparent significance of its existence. For example, the U.S. Postal Service publicly romanticizes its universal service function in a manner that surely is disproportionate to the magnitude of that undertaking. In May 1995, for example, the Postal Service took out a quarter-page advertisement on the op-ed page of the New York Times to tout its deliveries by bush pilot above the Arctic Circle and by mailboat in the Louisiana bayous. ${ }^{217}$ Those deliveries to remote, high-cost areas also include

210. Id. at 67.

211. Id.

212. CANADA POST ANNUAL RePORT, supra note 17, at 2.

213. See Clermont Testimony, supra note 52.

214. CANAda POST CORPORATE PlaN, supra note 8, at 7.

215. Id.

216. See Robert W. Crandall \& J. Gregory Sidak, Competition and Regulatory Policies for Interactive Broadband Networks, 68 S. CAL. L. REV. 1203, 1213-28 (1995).

217. N.Y. Times, May 12, 1995, at A31 (Postal Service advertisement). The weekday price of a quarter-page advertisement running one time on the op-ed page of the New York Times is $\$ 18,315$ (U.S.). 
Supai, Arizona, where, the Postal Service explains, pack mules must negotiate eight miles of trails down the south rim of the Grand Canyon to deliver not only mail, but also food and furniture to the Havasupai Indian Reservation below. ${ }^{218}$ One wonders how the Havasupai managed to procure food and furniture before the U.S. mail came along. One can ask similar questions about groceries and tires delivered by the U.S. Postal Service to the Alaskan wilderness. ${ }^{219}$

Canada Post's policy of uniform pricing for standard letter mail may have an efficiency justification in the sense that it reduces the transaction costs of sending mail. Of course, it also has a powerful distributional effect, as the Supai mule trail illustrates in the United States. Given the differences in the cost of delivery between urban and rural areas, uniform pricing necessarily implies that some customers will subsidize other customers. Is public control of postal services the only means to achieve ubiquity of service, uniformity of pricing, and subsidies to high-cost delivery areas? The answer is plainly no. Is public control the most efficient means of achieving those social policies? Again, no.

First, private firms like Federal Express and United Parcel Service provide ubiquitous service at a uniform price, which in turn implies a subsidization of high-cost recipients of overnight mail and parcels. The accomplishment of such distributional effects therefore does not require either public ownership or control of postal services.

Second, private firms demonstrate regularly that they are better able than Canada Post to provide service at low cost. Political judgment has determined that certain services, such as delivery of goods to the North, should be priced below cost. ${ }^{220}$ Canada Post contracts out much of that service to private carriers. ${ }^{221}$ The continued reliance on Canada Post's monopoly over letter mail, however, forecloses experimentation with alternative mechanisms for the private provision of postal service to high-cost areas, even under continued government subsidies. In particular, in the absence of the statutory monopoly, it would be possible for the federal government to invite bids from private firms to provide mail service to a particular remote area and to assume the obligation of being the carrier of last resort. Postal customers in that region would continue to pay a nationally uniform price for mail, and private firms would submit competing bids to provide such service for the lowest subsidy to be paid by the federal government. The process would not fundamentally differ from that by which the baker submitting the lowest bid

Telephone interview between Marshall Smith, American Enterprise Institute, and Janine Lloyd, New York Times Advertising Dep't, May 23, 1995.

218. U.S. POSTAL SER VICE, History OF THE UnITEd STATES POSTAL SERVICE 20 (1993).

219. See The Economics of Mail Delivery: Discussion, in GoverNING THE POSTAL SERVICE, supra note 160 , at 21-22.

220. Price Waterhouse Strategic ReVIEW, supra note 14, at 14.

221. Id. 
is awarded the contract to supply bread to a military base. An alternative method of providing universal service would be to give subsidies directly to postal customers and then allow Canada Post (or any other carrier) to charge customers a price reflecting the true cost of service.

In short, the pursuit of social goals does not require Canada Post to have a statutory monopoly or to distort postal pricing. The federal government can instead provide subsidies through either of the contracting mechanisms just described. Universal service does not require public control of postal services. Of course, to say that alternative financing schemes for universal service exist is not to say that it would be politically easy to adopt them in lieu of the current scheme of cross-subsidies. The schemes developed by federal and state governments to provide "universality" across infrastructure industries, including public utilities, have repeatedly involved the internal collection of the cross-subsidy by the franchised monopoly firm that provides commercial services of the same kind. ${ }^{222}$ Integrating universal and commercial services in a monopoly provider's "internal tax system" helps to conceal the magnitude and recipients of the cross-subsidy. If those facts were made explicit, the cross-subsidy might prove to be politically embarrassing and cause voters to demand that Parliament end or reduce it.

\section{Public Provision Is Not Needed to Ensure the Integrity of the Mail Stream}

The need to maintain the security of the mail stream is another justification given for public ownership of Canada Post. It is unlikely, however, that a public enterprise is better able than private firms to provide secure communications and shipments. The experience from the United States indicates that the Postal Service's own record of reliability and security is problematic. The purpose of the following discussion is not to impute to Canada Post the derelictions of the U.S. Postal Service, but rather to provide a case study of how one prominent public enterprise failed spectacularly in its mission to provide a secure mail-stream.

\section{Private Provision of Secure Communications and Deliveries}

Public control of postal services is not needed to ensure security for at least three reasons. First, the private sector already offers consumers reliable alternatives to the mail for secure communications, such as parcel post and express mail. Private firms could easily extend those services to letter mail. Moreover, the reliability argument is obsolete because it neglects other reliable alternatives to communication by mail such as newspapers, radio,

222. See Crandall \& Sidak, supra note 216 , at 1213-28. 
television, telecommunications, and electronic communication (e.g., e-mail and facsimile).

Second, the private sector offers consumers an array of security options for their communications and shipments. The market offers many types of security arrangements ranging from specialized couriers to armored cars. Parcel delivery companies have developed bar-coded tracking systems that ensure security and accuracy in locating packages. Those innovations and varied product offerings of private firms respond to the fact that the security needs of individual mailers vary. In contrast, public control of the postal system is more likely to produce a uniform level of security that is not tailored to individual needs and risk preferences.

Third, Canada Post already contracts out the transportation of mail to private airlines, railroads, and trucking firms. ${ }^{223}$ That fact indicates that the federal government does not consider itself the only party trustworthy enough to handle the mail.

\section{Reputational Effects of Criminal Wrongdoing or Negligence by Postal Employees}

In the United States, recent press reports of the Postal Service's improper handling of the mail present evidence that public ownership and control of the postal system does not guarantee the integrity of the mail system. Empirical studies have established that U.S. Postal Service workers earn a wage premium of approximately $20 \%$ over the earnings of workers performing comparable tasks in the private sector. ${ }^{224}$ If the Postal Service were unique in its ability to ensure the integrity of the mail stream, that wage premium could be regarded as a bonding mechanism-a quasi rent that postal employees would lose if discharged from their jobs for compromising the integrity of the mail stream. ${ }^{225}$ Anecdotal evidence leads one to reject that hypothesis, however, for in recent years the Postal Service has damaged its own reputation for honesty and reliability. During 1994, newspapers and magazines carried numerous stories, some of them simply bizarre, of postal workers who had destroyed or misappropriated mail.

In the Chicago area, caches of undelivered mail were found either abandoned or burning. During the first three and a half months of 1994, postal inspectors found nearly 70,000 pieces of undelivered mail in Chicago, including 5,000 pieces of undelivered first class mail either stashed behind

223. Clermont Testimony, supra note 52.

224. Jeffrey M. Perloff \& Michael L. Wachter, A Comparative Analysis of Wage Premiums and Industrial Relations in the British Post Office and the United States Postal Service, in COMPETTTON AND INNOVATION IN POSTAL SERVICES, supra note 112, at 115-121.

225. See Benjamin Klein \& Keith B. Leffler, The Role of Market Forces in Assuring Contractual Performance, 89 J. POL. ECON. 615 (1981). 
the home of a dismissed postman or in the trunk of another postman's car. ${ }^{226}$ One postman was arrested and charged with delaying the delivery of the mail, a felony carrying a maximum penalty of five years in prison. ${ }^{227} \mathrm{~A}$ month later, firefighters battling a blaze found sacks of mail bearing Chicago addresses in a postman's condominium. ${ }^{228}$ Postmaster General Marvin Runyon subsequently dismissed the mail-burning incident in Chicago as an unfortunate aberration that had attracted excessive attention. ${ }^{229}$ To the contrary, the incidents in Chicago were not isolated events, for similar destruction or misappropriation of mail was occurring in Washington, D.C.

In July 1994, the Postal Service disclosed that a Price Waterhouse study revealed that Washington, D.C., had the worst mail service in the nation during the quarter ending May 27,1994 , with only $60.6 \%$ of first class mail arriving on time. ${ }^{230} \mathrm{~A}$ week later, a surprise audit of three postal facilities in greater Washington, D.C., by the U.S. Postal Inspection Service uncovered more than three million pieces of undelivered mail, some of it dating to February 1994, and most of it stashed in parked trailers. ${ }^{231}$ The trade press reported that "[p]ostal inspectors noted in their report that postal workers were reluctant to report delays in handling mail because it could possibly ruin their careers, subjecting them to harsh criticism by supervisors."232

Although the cumulative effect of such press reports on the reputation of the Postal Service is difficult to quantify, clearly they can only reduce consumer confidence in this public enterprise. By comparison, a private firm whose reputation is sullied by revelations of negligence or intentional misconduct suffers a statistically significant loss in its stock price. ${ }^{233}$ Moreover, the loss exceeds the amount of expected criminal penalty or civil damage award. ${ }^{234}$ Economists attribute that decrement of market value to a reputational penalty that the capital markets impose on the firm in the

226. More Undelivered Mail Found in Chicago, N.Y. TIMES, Apr. 16, 1994, at 6.

227. Id. See also 18 U.S.C. $\$ 1703$ (1994) (delay or destruction of mail or newspapers).

228. Firemen Find Sacks of Mail, N.Y. TIMES, May 10, 1994, at A12.

229. Marvin Runyon, U.S. Postmaster General, Address to the National Press Club, Washington, D.C., Jan. 31, 1995, available in LEXIS, News Library, Fednew File.

230. Bill McAllister, Millions of Letters Undelivered; Local Facilities Held Unprocessed Mail, WASH. Post, July 20, 1994, at A1; Bill McAllister, Post Office Acts to End Backlog; Overtime Is Ordered for Area Mail Clerks Today and Sunday, WASH. POST, July 23, 1994, at A1; Bill Miller, Post Offices Playing Catch-up; Workers on Overtime to Speed up Delivery, WASH. POST, July 24, 1994, at B1.

231. Paul M. Alberta, Probers Find Mail Stashed in Trailers, DM NEwS, July 25, 1994, at 3, available in LEXIS, Nexis News Library, DMNEWS file. The stashed mail included 2.3 million pieces of bulk business mail and 800,000 first class letters in parked Postal Service trailers at Capitol Heights, Maryland, more than 900,000 pieces of unprocessed mail at Merrifield, Virginia, and thousands of first class letters at Washington's main post office. Id.

232. Id.

233. See Jonathan M. Karpoff \& John R. Lott, Jr., The Reputational Penalty Firms Bear from Committing Criminal Fraud, 36 J.L. \& ECON. 757 (1993); Mark L. Mitchell \& Michael T. Maloney, Crisis in the Cockpit? The Role of Market Forces in Promoting Air Travel Safety, 32 J.L. \& ECoN. 329 (1989).

234. Karpoff \& Lott, supra note 233 , at 796-97. 
expectation that the occurrence in question may signal that the firm's future earnings may suffer as a result of further derelictions. Of course, no such barometer exists for the market value of the Postal Service because it is wholly owned by the federal government. No fraction of the ownership of the Postal Service trades over a national exchange, and thus one cannot employ the familiar event-study methodology from corporate finance to evaluate the reputational harm to the Postal Service from revelations that its employees had stolen or destroyed mail or had knowingly failed to deliver it in a timely manner.

Private firms and the Postal Service differ in one other significant respect in terms of how they bear the costs of criminal wrongdoing or negligence by their employees. In a private firm, the harm to reputation is also borne individually by managers through diminished lifetime earnings resulting from their association with illegal or negligent conduct. In the Postal Service, however, there is at least anecdotal evidence that intentional misconduct by postal managers has failed to elicit significant penalties in terms of termination or demotion, let alone civil or criminal prosecution. For example, The New Yorker reported that the mail processing director for Chicago

spent two hundred thousand dollars of [Postal Service] maintenance funds to refurbish her office suite with hardwood kitchen cabinets, a marble bathroom, and an air-conditioner for each of the suite's seven windows. Rumor has it that word of the renovation quite literally leaked out when water from [her] whirlpool bath came through the ceiling of the express-mail unit, two floors down. ${ }^{235}$

This postal manager was punished by being transferred, without any reduction in pay, to a suburban Chicago facility where her husband was the plant manager. ${ }^{236}$

\section{E. Recapitulation}

Public provision of the full range of postal services is no longer necessary. Canada Post is not a natural monopoly. The absence of insurmountable barriers to entry into postal delivery has allowed extensive provision of postal services on a competitive basis and will continue to enable private firms to provide additional mail services as regulation permits. In the absence of Canada Post's statutory monopoly over letter mail, one would observe competitive provision of all classes of mail service.

The contemporary rationales offered for continuing the public provision of the full range of postal services are (1) to ensure ubiquity of service, (2) to

235. Jonathan Franzen, Lost in the Mail, THE NEW YORKER, Oct. 24, 1994, at 72.

236. Id. 
allow for uniformity of pricing throughout the country, and (3) to ensure the integrity of the mail stream. On closer examination, it is clear that private firms, whose managers are obliged to maximize profit for their shareholders, can be relied upon to a greater extent than Canada Post to supply secure delivery of letters and parcels. Further, in the presence of a funding mechanism for universal service that is more attentive to the goal of maximizing consumer welfare than is the current method of rate averaging, public control of postal services would be unnecessary to ensure ubiquity of service and geographic uniformity of pricing and quality. Therefore, the competitive provision of letter mail would not compromise universal service, and it would seem more likely to increase rather than decrease the integrity and efficiency of the mail stream because of the superior incentive structures facing managers in private firms.

\section{The Competitive Problems of Postal Pricing and Regulations}

In reviewing the mandate of the Canada Post Corporation, it is imperative to consider the competitive problems of postal pricing and regulations and for Canadian policy makers to avoid the erroneous reasoning of the General Accounting Office's study of the U.S. Postal Service. ${ }^{237}$ Unlike a private firm in a regulated industry in the United States, Canada Post is not subject to the demanding oversight of a provincial public utility commission or a federal regulatory agency. From a competitive perspective, the principal harm that regulatory oversight can prevent is the misallocation of costs by Canada Post from competitive classes of mail to letter mail, which is protected by a statutory monopoly.

\section{A. Preventing Anticompetitive Cost Misallocation by Canada Post}

In regulated private industries one way of reducing the incentive and opportunity for anticompetitive cross-subsidization is to replace cost-ofservice regulation with price caps. ${ }^{238}$ Canada Post, however, is not subject to price caps. Moreover, it is doubtful that price caps would even be feasible for Canada Post.

237. U.S. General accounting Office, U.S. Postal Service: Pricing Postal Services in a COMPETTIVE ENVIRONMENT (1992) [hereinafter GAO REPORT].

238. See BRIDGer M. MITCHELl \& INGo Vogelsang, Telecommunications PRicing: THEORY AND PRACTICE 167-75, 276-85 (1991); DAVID E. M. SAPPINGTON \& DENNIS L. WEISSMAN, DESIGNING INCENTIVE REgULATION FOR THE TELECOMMUNICATIONS INDUSTRY (1996); Ronald R. Braeutigam \& John C. Panzar, Diversification Incentives Under "Price-Based" and "Cost-Based" Regulation, 20 RAND J. ECON. 373, 387-90 (1989); Ronald R. Braeutigam \& John C. Panzar, Effects of the Change from Rate-of-Retum to Price-Cap Regulation, 83 AM. ECON. REV. PAPERS \& PROC. 191 (1993). 


\section{The Logic of Price Caps}

Price caps resemble the phenomenon of regulatory lag-the general delay in the responses of those approving Canada Post's rates to changes in cost or market conditions. ${ }^{239}$ In addition, price caps may allow the firm pricing flexibility and can reduce the cost of developing annual five-year plans.

Suppose that the firm's prices are set on the basis of current costs, and the firm succeeds in reducing those costs substantially. Suppose further that, say, two years elapse before the firm would be required to cut its prices correspondingly. Then the firm would enjoy two years of superior profits as its reward for improved efficiency. That process mimics a competitive market, where a cost-cutting innovator enjoys superior but temporary profits. Those higher profits end when rivals introduce their own cost-reducing innovations and wipe out the competitive advantage temporarily enjoyed by the earlier innovator.

The built-in regulatory lag at the heart of the price-cap approach must be substantial because otherwise firms will have no effective incentive to undertake the heavy costs and risks of innovation, and society will be the loser. On the other hand, the lag, like the life of a patent, must not be infinite, lest the consuming public be forced to forgo the benefits of lower prices that the competitive market normally transmits to it.

Regulatory lag thus supplies the incentive required to elicit innovation and productivity growth, with one critical exception. When inflation is substantial, regulatory lag delays the adjustment of output prices to compensate for inflationary increases in nominal input costs. That delay squeezes the profits of the regulated firm and undercuts both its incentive and its ability to invest in innovation. To deal with the inflation problem, the price-cap arrangement uses the following familiar procedures. First, an initial price ceiling is determined on the basis of stand-alone cost or a defensible proxy. Second, the price ceiling is permitted to rise automatically each year by a percentage equal to the rise of 'some widely accepted index of inflation, such as the consumer price index (CPI), after subtracting some number, $X$, from the percentage increase in that price index. The arrangement is often referred to as "CPI - $X$." Third, $X$ is calculated from the industry's differential rate of productivity growth in the past, or as a target rate of productivity growth for the industry.

The logic of price caps is straightforward: The firm is permitted a percentage increase in the profit margin on its product that precisely equals the amount by which its productivity performance exceeded the target. The opposite is experienced by a firm whose productivity performance falls short of the

239. Indeed, although only Canada Post's monopoly rates are regulated, the corporation attributed the consolidated net loss of $\$ 69$ million that it reported for 1994-95 primarily to the delay in rate action approval. CANADA POST CORPORATE PLAN, supra note 8, at 5. 
target. In sum, under price caps, the firm whose productivity increase exceeds the norm will enjoy higher returns exactly commensurate with its achievement, while the firm with poor productivity performance will automatically be penalized correspondingly.

Price caps do more than induce the private firm to minimize its cost of production. They also reduce the incentive for the firm to cross-subsidize new lines of business through the misallocation of costs, for the firm may charge up to its maximum price whether or not its accounting costs for the regulated service change. In that manner, price caps attenuate the link that rate-ofreturn regulation creates between the regulated firm's realized production costs and its allowed earnings. Under rate-of-return regulation, the firm can raise its allowed earnings whenever it can mischaracterize costs incurred in the production of unregulated products as having been incurred in the production of regulated products. Under price-cap regulation, however, the firm is not allowed higher revenues from regulated services when the costs of those specific activities rise; thus, the firm's ability to increase its earnings by assigning accounting costs from its unregulated services to its regulated services is decreased. This decreased ability to profit from cost misallocation correspondingly reduces the firm's incentive to attempt cross-subsidization.

\section{Price Caps and Canada Post}

In contrast to a private firm subject to price caps, Canada Post has the potential to engage in anticompetitive cross-subsidization, although, as was noted earlier, the Bureau of Competition Policy made no such finding in authorizing Canada Post to acquire a $75 \%$ interest in Purolator. ${ }^{240}$ Canada Post is not subject to any explicit price-cap regulation, and its rate changes are authorized relatively quickly compared with public utilities commissions' authorization of rate changes in the United States. ${ }^{241}$ Indeed, the statutory requirement that Canada Post publish its proposed rate modifications in the Canada Gazette for public and governmental review for sixty days and that the Governor in Council accept or reject the proposed rate regulation within sixty days after Canada Post has responded to that review, while desirable on grounds of administrative efficiency, incidentally contributes to the inability of postal rates to resemble price caps. ${ }^{242}$ Under such circumstances, not only is Canada Post able to allocate common fixed costs arbitrarily across classes of mail, but Canada Post is more able than a regulated private firm (such as a U.S. local exchange carrier) to fail to attribute costs that can be causally traced to a particular class of mail-particularly a class of mail, such as parcel

240. BUREAU NEWS RELEASE, supra note 147.

241. For proposals to subject the U.S. Postal Service to price caps, see Michael A. Crew \& Paul R. Kleindorfer, Pricing, Entry, Service Quality, and Innovations Under a Commercialized Postal Service, in GOVERNING THE POSTAL SERVICE, supra note 160, at 150, 161-67.

242. Canada Post Corporation Act, R.S.C., ch. C- $10, \S 20$ (1985) (Can.). 
post or overnight mail, for which Canada Post experiences substantial competition. One would expect cost misallocation by Canada Post to be an increasing function of the share of total costs that Canada Post asserts that it cannot attribute to any particular class of mail.

\section{B. Incorrect Measurement and Misallocation of Attributable Costs}

Canada Post has several major classes of mail including lettermail, admail, parcel service, and express mail. Such product categories are an arbitrary segmentation of the mail market based on the characteristics of the mailer. The categories exist to facilitate rate-setting and do not necessarily conform to market segments that might be identified today for pricing and marketing purposes.

\section{Cost-of-Service Regulation of the U.S. Postal Service}

A competitive firm sets price on the basis of its costs, its customers' willingness to pay, and the anticipated prices that the firm's actual and potential competitors will charge for their products. Unlike competitive firms, Canada Post sets price on the basis of accounting measures of operating costs and capital expenditures. In the case of the U.S. Postal Service, the Postal Rate Commission begins by determining the Postal Service's revenue requirement on the basis of projected levels of demand for the various classes of mail. Costs for a "test year" in the future are estimated on the basis of those estimated demand levels, expected inflation rate, and estimated productivity. If estimated total costs would exceed estimated revenues in the test year, using existing rates, the Postal Rate Commission recommends rate increases. The higher rates that would enable the Postal Service to break even reflect the fact that demand would fall (and hence total costs would change) as rates rise in accordance with the relevant price elasticities.

The prices established by a regulated firm that offers multiple products and services, or that distinguishes between multiple customer classes, are referred to as its rate structure. In the United States, after the Postal Rate Commission determines the Postal Service's revenue requirement, it addresses cost attribution and rate design. Each class must cover its attributable costs and make at least some contribution to the recovery of institutional costs. Understandably, great controversy surrounds the determination of whether a cost is attributable to a particular class of mail and how institutional costs should be apportioned among the various classes of mail. ${ }^{243}$

243. For a discussion of the mechanics of a Postal Rate Commission case, see Crew \& Kleindorfer, supra note 241, at 160; George Hall, Regulatory Systems for Postal Rates, in REgULATION AND THE NATURE OF POSTAL AND DELIVERY SERVICES, supra note 160, at 221. Because the Postal Service has no shareholders, the form of cost-of-service regulation to which it is subject differs somewhat from the cost-of-service regulation applied to private firms: 


\section{Tests for Cross-Subsidies in Multiproduct Firms}

A break-even regulated rate structure is said to be free of cross-subsidies if and only if the prices satisfy the stand-alone cost test. ${ }^{244}$ Stand-alone cost refers to the firm's long-run total cost of each service operated separately. The stand-alone cost test requires that the revenues generated from either of two services not exceed the stand-alone cost of providing that service. If the revenues from one service do exceed its stand-alone cost while the revenues from the other service do not cover stand-alone costs, then the first service is providing a cross-subsidy to the other service ${ }^{245}$ The test for cross-subsidization demonstrates that the customers of the service providing the cross-subsidy would be better off if they could obtain that service independently of the other service.

A regulated firm's rate structure also can be said to be free of cross-subsidies if and only if the prices satisfy the incremental cost test, which is equivalent to the stand-alone cost test for a regulated rate structure. ${ }^{246}$ When applying the incremental cost test, revenues generated by each service must cover the incremental cost of providing that service. ${ }^{247}$ The rationale for the incremental cost test is the requirement that each service must generate revenues that at least cover the additional cost of producing that service. If not, the other service is providing a cross-subsidy, and the customers of the other service would be better off receiving their service independently, at its stand-alone cost.

If a firm is regulated, it is desirable to design a rate structure that is free of cross-subsidies. Otherwise, the economic incentives can lead to allocative inefficiency. Customers receiving the subsidy do not observe the full economic costs of their service and consequently demand an inefficiently high

The testimony on the allowed rate of return, which is paramount in traditional utility regulation, is not part of postal rate hearings. If the utility regulator allows a higher rate of return, the stockholders potentially stand to benefit. In postal service regulation, however, there is not the same direct concern with rate of return. The Postal Service has a break-even requirement, which includes covering interest payments on its borrowing. The requirement to establish an opportunity cost of capital, the basis of most rate-of-return testimony in utility cases, is not present in postal rate cases.

Crew \& Kleindorfer, supra note 241 , at 160 . For a discussion of cost-of-service regulation of private firms, see SPULBER, supra note 161, at 271-79.

244. See, e.g., BAUMOL, PANZAR \& WILLIG, supra note 161 , at 352-53; BAUMOL \& SIDAK, supra note 172 , at 81 .

245. The definition of the stand-alone cost test is given in terms of two services. In the case of more than two services, the test requires that no group of services subsidize any other group of services.

246. See BAUMOL \& SIDAK, supra note 172, at 57, 81-83; WILlIAM J. BAUMOL, SUPERFAIRNESS APPLICATIONS AND THEORY 113-20 (1986).

247. The incremental cost test is defined here for only two services. In the case of more than two services, the revenues generated by each group of services must cover the incremental cost of providing that group of services. 
amount; customers providing the subsidy demand an inefficiently low amount or seek bypass alternatives that may be uneconomic under some conditions.

Canada Post's rate structure has the potential to include various types of cross-subsidies. One method of cross-subsidization is uniform pricing of postal delivery regardless of origin or destination. Another method is inappropriate accounting rules that misallocate costs. The differences in transportation and delivery costs thus are not reflected in the postal rates. Consequently, some mailers are subsidizing others. Other types of explicit subsidies exist, including franking privileges and targeted discounts, such as reduced postage rates on second class publishers' mail.

\section{Attributable Costs and Institutional Costs}

Putting aside explicit discounts, the method by which Canada Post's rates are established may contain a number of implicit cross-subsidies. Those types of cross-subsidies result from incorrect measurement of costs. One can distinguish two types of costs: attributable costs, which can be identified with the costs of specific services, and institutional costs, which refer to joint and common costs that cannot be attributed to any specific service.

Attributable costs generally are variable or "volume-sensitive" costs, such as labor and vehicles that can be assigned to specific types of sorting, collection, or delivery. Attributable costs also include fixed costs specifically incurred for particular types of mail. Institutional costs are fixed overhead and capital costs that are not volume-sensitive and do not correspond to any specific sorting, collection, or delivery activities. If attributable costs are correctly determined and prices for each service reflect those costs, arbitrary allocations of joint and common costs (that is, institutional costs) yield subsidy-free rate structures. ${ }^{248}$ That proposition means that there is generally a wide range of subsidy-free rate structures. If regulators incorrectly classify some attributable costs as institutional costs, however, then accounting rules for allocating indirect costs can easily produce cross-subsidization. For example, until the U.S. Postal Rate Commission disapproved the practice in 1979, the U.S. Postal Service characterized advertising expenses for express mail as institutional costs rather than attributable costs of that particular service offering. ${ }^{249}$

To see the extent to which costs can be shifted to the institutional category, consider the evidence from the U.S. Postal Service as shown in Table 1. Of the U.S. Postal Service's twenty cost segments, sixteen have no specific fixed costs, and three have insignificant specific fixed costs. The one remaining category, "other accrued expenses" (cost segment 20), has only

248. SPULBER, supra note 161, at 127-131.

249. Opinion and Recommended Decision, at 256-57, app. J (Postal Rate Comm'n 1981) (No. R80-1) (discussing 1979 proceeding). 
4.9\% specific fixed costs, mostly for equipment depreciation; but even here, $38.8 \%$ of costs are institutional. In other words, the Postal Service recognizes practically no category-specific fixed costs. Therefore, almost all fixed costs are treated as joint and common costs under the institutional cost label. Such a categorization of costs is difficult to believe. How can almost $40 \%$ of total cost be joint and common fixed cost while not even 1 percent of total cost is category-specific? In other words, while the Postal Service's estimates of its fixed costs are high, virtually all of those fixed costs are incurred jointly across multiple cost categories, rather than being incurred on a segmentspecific basis. $^{250}$

A possible explanation for this phenomenon might be that the "cost driver" selected by the U.S. Postal Service is not the appropriate measure of the sensitivity of costs to the economic activity. The Postal Service divides its twenty cost segments into about sixty-five cost components and 100 subcomponents. ${ }^{251}$ For each cost element, the Postal Service identifies a "cost driver" that in its opinion "reflects the essential activity of that element."252 For example, "carrier access costs are driven by the number of stops made by the letter carrier to deliver mail, and carrier 'load' costs are driven by pieces of each mail shape that a letter carrier loads into [a] mail receptacle." ${ }^{, 253}$ The Postal Service calculates an "elasticity of cost" known as the "volume variability" of the cost. The elasticity of cost is the percentage change in cost divided by the percentage change in volume that "causes" the cost to increase. Then, the Postal Service estimates marginal cost by multiplying the total cost of the class by the elasticity of cost and dividing by volume. That computation estimates the change in cost for a change in volume. Attributable costs are calculated by multiplying marginal cost times volume and adding any specific fixed cost. ${ }^{254}$

250. Of course, those cost categories do not correspond to product lines. Analysis of cost allocation by product line would shed further light on the likelihood of cross-subsidies between products.

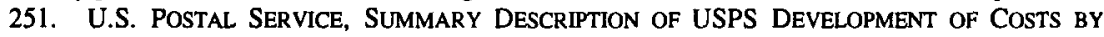
SEGMENTS AND COMPONENTs, tbl. 2, app. H (Calculating Postal Product Costs) (1994) [hereinafter COSTS BY SEGMENTS AND COMPONENTS]

252. Id. at $\mathrm{H}-5$.

253. Id. at $\mathrm{H}-4$.

254. Id. at $\mathrm{H}-3$. 
TABLE 1

Percentage Summary OF FY 1993 U.S. POSTAL SERVICE

COSTS BY COST SEGMENT AND CLASSIFICATION

\begin{tabular}{|c|c|c|c|c|c|}
\hline \multirow[b]{2}{*}{ Cost Segment } & \multirow[b]{2}{*}{$\begin{array}{l}\text { Total } \\
\text { Accrued }\end{array}$} & \multicolumn{4}{|c|}{ Attributable Costs } \\
\hline & & Total & $\begin{array}{l}\text { Total } \\
\text { Volume- } \\
\text { Variable }\end{array}$ & $\begin{array}{l}\text { Specific- } \\
\text { Fixed }\end{array}$ & Institutional \\
\hline 1. Postmasters & 100.0 & 17.8 & 17.8 & - & 82.2 \\
\hline \begin{tabular}{|l|} 
2. \\
$\begin{array}{l}\text { Supervisors } \\
\text { and Technical } \\
\text { Personnel }\end{array}$ \\
\end{tabular} & 100.0 & 54.8 & 54.8 & - & 45.2 \\
\hline 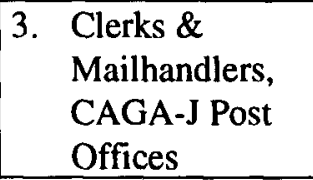 & 100.0 & 87.2 & 86.7 & .5 & 12.8 \\
\hline $\begin{array}{l}\text { 4. Clerks, CAG K } \\
\text { Post Offices }\end{array}$ & 100.0 & 60.2 & 60.2 & - & 39.8 \\
\hline 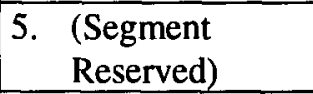 & - & - & - & - & - \\
\hline $\begin{array}{|ll|}\text { 6. } & \text { City Delivery } \\
\text { Carriers, Office } \\
\text { Activity } \\
\end{array}$ & 100.0 & 89.9 & 89.9 & - & 10.1 \\
\hline $\begin{array}{|ll|}\text { 7. } & \text { City Delivery } \\
\text { Carriers, Street } \\
\text { Activity }\end{array}$ & 100.0 & 28.9 & 28.9 & - & 71.1 \\
\hline $\begin{array}{|ll|}\text { 8. } & \begin{array}{l}\text { Vehicle Service } \\
\text { Drivers }\end{array} \\
\end{array}$ & 100.0 & 47.3 & 47.3 & $=$ & 52.7 \\
\hline $\begin{array}{ll}\text { 9. } & \text { Special } \\
& \text { Delivery } \\
& \text { Messengers } \\
\end{array}$ & 100.0 & 52.4 & 52.4 & - & 47.6 \\
\hline 10. Rural Carriers & 100.0 & 39.2 & 39.2 & - & 60.8 \\
\hline $\begin{array}{l}\text { 11. Custodial and } \\
\text { Maintenance } \\
\text { Services } \\
\end{array}$ & 100.0 & 62.2 & 62.2 & - & 37.8 \\
\hline
\end{tabular}


TABLE 1 (CONTINUED)

PERCENTAGE SUMMARY OF FY 1993 U.S. POSTAL SERVICE COSTS BY COST SEGMENT AND CLASSIFICATION

\begin{tabular}{|c|c|c|c|c|c|}
\hline \multirow[b]{2}{*}{ Cost Segment } & \multirow[b]{2}{*}{$\begin{array}{c}\text { Total } \\
\text { Accrued }\end{array}$} & \multicolumn{4}{|c|}{ Attributable Costs } \\
\hline & & Total & $\begin{array}{c}\text { Total } \\
\text { Volume- } \\
\text { Variable }\end{array}$ & $\begin{array}{l}\text { Specific- } \\
\text { Fixed }\end{array}$ & Institutional \\
\hline $\begin{array}{l}\text { 12. Motor Vehicle } \\
\text { Service }\end{array}$ & 100.0 & 20.1 & 20.1 & - & 79.9 \\
\hline $\begin{array}{l}\text { 13. Miscellaneous } \\
\text { Operating Costs }\end{array}$ & 100.0 & 2.9 & 2.9 & - & 97.1 \\
\hline $\begin{array}{l}\text { 14. Purchased } \\
\text { Transportation }\end{array}$ & 100.0 & 86.5 & 86.5 & - & 13.5 \\
\hline $\begin{array}{l}\text { 15. Building } \\
\text { Occupancy } \\
\text { Costs }\end{array}$ & 100.0 & 70.2 & 70.2 & - & 29.8 \\
\hline $\begin{array}{l}\text { 16. Supplies and } \\
\text { Services }\end{array}$ & 100.0 & 58.8 & 56.8 & 2.0 & 41.2 \\
\hline $\begin{array}{l}\text { 17. Research, } \\
\text { Development, } \\
\text { and Engineering }\end{array}$ & 100.0 & 一 & 一 & - & 100.0 \\
\hline $\begin{array}{l}\text { 18. Administration } \\
\text { and Regional } \\
\text { Operations }\end{array}$ & 100.0 & 35.3 & 35.2 & .1 & 64.7 \\
\hline $\begin{array}{l}\text { 19. General } \\
\text { Management } \\
\text { Services } \\
\end{array}$ & 100.0 & - & - & - & 100.0 \\
\hline $\begin{array}{l}\text { 20. Other Accrued } \\
\text { Services }\end{array}$ & 100.0 & 61.2 & 56.3 & 4.9 & 38.8 \\
\hline Total & 100.0 & 61.0 & 60.7 & .3 & 39.0 \\
\hline
\end{tabular}

SOURCE: COSTS BY SEGMENTS AND COMPONENTS, supra note 251, table 2, at xi. 
The product of marginal cost times output, however, is an imperfect measure of variable cost. Suppose, for example, that variable costs are given by a quadratic function,

$$
C(Q)=Q^{2}
$$

so that marginal cost equals $2 Q$. Then, the product of marginal cost and volume is $M C \times Q=2 Q^{2}=2 C(Q)$. Such an approach doubles the level of variable cost. Suppose instead that variable costs exhibit some economies of scale,

$$
C(Q)=Q^{1 / 2}
$$

so that marginal cost equals $.5 Q-1 / 2$. Then, the product of marginal cost and volume is $M C \times Q=.5 Q^{1 / 2}=.5 C(Q)$, which cuts in half the level of variable cost. Clearly, different specifications of the variable cost function can lead to significant errors in estimating attributable cost, even if marginal cost can be estimated accurately. ${ }^{255}$

The U.S. Postal Service uses several methods to calculate the attributable cost of a product. One approach, the "volume-variability" method, assigns costs on the basis of the "cost driver" used to calculate the cost elasticity. For example, the Postal Service uses the number of stops as the cost driver for city carrier access. ${ }^{256}$ The Postal Service suggests that such a measure is preferable to similar fully distributed cost methods using mail volume. An arbitrary choice of the cost driver, however, can significantly affect cost estimates. Those effects, in turn, would entail variation in the cost estimates used as a basis for Ramsey pricing, or any other regulated pricing methods for that matter.

A second approach that the U.S. Postal Service uses to calculate the attributable cost of a product is the "constructed marginal cost measure." The Postal Service calculates the effect of a cost driver on cost, and the effect of mail volume on the cost driver, to obtain the marginal cost of mail delivery in terms of mail volume. ${ }^{257}$ Again, the accuracy of those estimates will affect the results of Ramsey pricing calculations.

It is sometimes difficult to verify independently whether the cost drivers selected by the U.S. Postal Service provide an accurate measure of the economic activities of the enterprise. The ability to evaluate the economic costs and returns from the Postal Service's activities is not only important for regulatory purposes. The Postal Service needs to have economically accurate

255. The Postal Service recognizes this problem in calculating incremental cost, which involves multiplying each unit by the marginal cost of that unit, id. at H-3. This method, however, does not appear to be used for the attributable cost calculation.

256. Id. at $\mathrm{H}-6$.

257. Id. at $\mathrm{H}-7$. 
information about its products and services to manage its own operations, determine the economic viability of its services, and prevent cross-subsidization. Accurate internal business information is necessary to make efficient investment decisions and to reduce or avoid economic losses.

\section{The Difficulty of Preventing Cross-Subsidization by Canada Post}

Canada Post is concerned that its prices and services are not competitive with those of its competitors. Canada Post seeks the flexibility to expand its range of services to compete with the large integrated carriers that have developed the logistics management services offered by its nonpostal competitors. $^{258}$ Such flexibility will surely include price flexibility. Essentially, price flexibility of this type requires a shifting of institutional costs away from markets in which Canada Post faces competition and toward the market in which it holds a statutory monopoly. Given the high likelihood of incorrect measurement of institutional costs and cost inefficiencies, such cost shifting can easily lead to cross-subsidization of competitive activities by Canada Post's captive customers.

There are few safeguards against such cross-subsidization. As explained earlier, the U.S. Postal Service can carry out a cross-subsidization program by following standard cost allocation rules if it can inflate the proportion of institutional costs. Moreover, since Canada Post already has a presence in the competitive markets for parcel post and express mail, it is difficult to distinguish incremental costs devoted to those activities from growth in institutional costs.

Market safeguards against cross-subsidization also are absent because of Canada Post's statutory monopoly for letter mail. Competitive firms generally cannot cross-subsidize because cross-subsidizing induces competitive entry. If a service offered by a firm is contributing greater revenues than its standalone cost, and if entry barriers are not excessive, then competitors will enter the market and profitably supply that service. If the markets providing subsidies are protected by statutory entry barriers, however, such competition cannot occur. The statutory monopoly over letter mail delivery gives Canada Post the potential to engage in cross-subsidization of competitive activities and to pass the cost along to captive customers.

A profit-maximizing firm generally does not have an incentive to crosssubsidize. Canada Post's behavior, however, suggests that it maximizes volume, which rises as the corporation expands into new services or reduces its prices relative to those of its competitors. Indeed, Canada Post has shown a willingness to suffer significant losses-for the year ended March 26, 1994, Canada Post's net loss was $\$ 259$ million-while maintaining or increasing volume, or while entering into or remaining in markets that private, competi-

258. CANADA POST CORPORATE PLAN, supra note 8 , at 8. 
tive firms have proven can be profitably served without government intervention. ${ }^{259}$ Such behavior by Canada Post is not consistent with profitmaximizing behavior (or, for that matter, its statutory mandate) but is consistent with the objective of maximizing volume and employment.

\section{Remedies for Cost Misallocation by Canada Post}

Three principal remedies would prevent Canada Post from misallocating cost. The first would be to open all postal markets to competition. Such a policy would eliminate the possibility of cross-subsidies in the rate structure of Canada Post and would wring out any of its economic inefficiencies because both of those conditions would create profitable opportunities for firms to enter the market and offer lower prices.

A second remedy, not mutually inconsistent with the first, would be to break up Canada Post along product lines to avoid any incorrect identification of attributable costs as being joint and common.

A third remedy would be an alternative to the first two: remove Canada Post from all markets but those in which it has a statutory monopoly so as to avoid the possibility that subsidies would flow from protected to competitive activities.

The policy recommendations in Part $\mathrm{V}$ will discuss the first and third alternatives in greater detail.

\section{Misuse of Ramsey Pricing Principles}

In the United States a misuse of Ramsey pricing principles underlies the GAO's recommendation that Congress grant the U.S. Postal Service the freedom to price according to the inverse elasticity rule. The same deficiency implicitly underlies Postmaster General Runyon's call for greater pricing flexibility. This section reviews the concept of Ramsey pricing and then shows why Canadian policy makers should avoid the errors of economic reasoning that arise in the arguments of the GAO and the Postmaster General.

\section{Ramsey Pricing}

Ramsey pricing is a method of allocating fixed costs and joint and common costs for a regulated firm or public enterprise. If it were feasible financially, economic welfare would be maximized by setting the price of each product equal to its marginal (or incremental) cost. If there are economies of scale, however, marginal cost pricing yields insufficient revenues to cover the firm's total cost. Prices must therefore exceed marginal cost for the

259. PRice Waterhouse Strategic ReVIEW, supra note 14 , at 13. 
firm to recover fixed costs and joint and common costs and thus continue to supply the goods in question.

But every deviation of price from marginal cost creates some inefficiency-first, because it provides an incentive for consumers to switch to those goods whose prices are raised only modestly relative to their true marginal cost, and second, because every rise in price restricts demand by cutting into consumer purchasing power. Ramsey pricing denotes those second-best prices that are Pareto optimal, subject to the requirement that they yield revenues sufficient to cover the total costs incurred by the supplier of the products in question. The damage to welfare is minimized if the firm can cover its revenue shortfall through smaller increases in the prices of the goods whose demands are elastic and through larger increases in the prices of goods whose demands are comparatively inelastic. ${ }^{260}$

Firms usually obtain Ramsey prices by maximizing the sum of consumer surplus and producer surplus subject to the constraint that the revenues the firm generates cover its costs. The standard approach to deriving Ramsey prices, however, is itself subject to theoretical dispute because it ignores effects on the distribution of income and assumes that the income effects of price changes are insignificant. ${ }^{261}$ Derivations of Ramsey prices often assume that a change in the price of one of the firm's products will not affect the demand for its other products. ${ }^{262}$ We review the derivation of Ramsey prices in Section C of Part IV of this Article.

Moreover, if the firm incorrectly characterizes attributable costs as joint costs (or vice versa), it will bias the Ramsey prices and preclude the welfaremaximizing result, as Section $C$ below demonstrates analytically. As noted earlier, the apparent need to allocate institutional costs by using demand factors grows in importance the more Canada Post is able, through questionable accounting practices, to count attributable costs as overhead. If instead such costs were correctly attributed to specific activities of Canada Post, many problems of cost allocation would disappear.

260. See Frank P. Ramsey, A Contribution to the Theory of Taxation, 37 ECON. J. 47 (1927). For a review of the subsequent literature, see William J. Baumol, Ramsey Pricing, in 4 THE NEW PALGRAVE: A DictionaRy OF ECONOMiCs 49-51 (John Eatwell, Murray Milgate \& Peter Newman eds., 1987); William J. Baumol \& David F. Bradford, Optimal Departures from Marginal Cost Pricing, 60 AM. ECON. REV. 265 (1970).

261. See SPULBER, supra note 161, at 166-68; Martin S. Feldstein, Distributional Equity and the Optimal Structure of Public Prices, 62 AM. ECON. REV, 32 (1972); Martin S. Feldstein, Equity and Efficiency in Public Sector Pricing: The Optimal Two-Part Tariff, 86 Q.J. ECON. 175 (1972).

262. The analysis of Frank A. Scott, Jr., Assessing USA Postal Ratemaking: An Application of Ramsey Prices, 34 J. INDUS. ECON. 279 (1986), and Roger Sherman \& Anthony George, Second-Best Pricing for the U.S. Postal Service, 45 S. ECON. J. 685 (1979), account for cross-elasticities of demand and income effects. Analyses that assume zero cross-price elasticities of demand include Baumol \& Bradford, supra note 260; O. A. Davis \& A. B. Whinston, Welfare Economics and the Theory of Second Best, 32 REV. ECON. STUD. I (1965); Abba P. Lerner, On Optimal Taxes with an Untaxable Sector, 60 AM. ECON. Rev. 284 (1970). See also Leonard Waverman, Pricing Principles: How Should Postal Rates Be Set?, in PERSPECTIVES ON POSTAL RATES 7 (Roger Sherman ed., 1980). 
2. The Error Underlying the GAO's Recommendation That the U.S. Postal Service Employ the Inverse Elasticity Rule

The GAO's recommendation that the U.S. Postal Service use the inverse elasticity rule is theoretically flawed because the GAO would have the Postal Service use estimates of the price elasticity of demand for first class mail that are predicated on regulatory barriers to entry into postal markets. According to the GAO, "[t]he Postal Service believes that demand factors should play a major role in overhead cost allocation, whereas the [Postal Rate] Commission places less weight on demand factors in its pricing decisions than the Postal Service does." ${ }^{263}$ In its report to Congress, the GAO recommends the following:

[T]o give the Postal Service more competitive flexibility, GAO believes Congress should reexamine the nine ratemaking criteria set forth in the Postal Reorganization Act and consider amending them to state that (1) in allocating institutional costs, demand factorsincluding elasticities of demand-are to be given a weight that takes into account the need to maintain the long-term viability of the Postal Service as a nationwide full-service provider of postal services and that (2) such use of demand factors will not be inconsistent with the rate criterion requiring the establishment of a fair and equitable rate schedule as long as each mail class recovers the direct and indirect costs attributable to that service and makes some contribution to institutional costs. Congress should also consider reexamining the provisions of section 403(c) of the Postal Reorganization Act to determine if volume discounting by the Postal Service would in fact result in "undue or unreasonable discrimination" among mailer and "undue or unreasonable preference" to a mailer. ${ }^{264}$

Even if a legitimate need for overhead cost allocation exists, the GAO has applied demand-based pricing rules with deceptive oversimplification to the operations of the U.S. Postal Service.

The demand for a firm's good is always more price elastic than the total market demand for that good-unless the firm is a monopolist protected by entry barriers, in which case the price elasticities of demand for the firm and the market closely correspond. Generally, the firm faces a demand function

263. GAO REPORT, supra note 237 , at 4.

264. Id. at 8-9. 
that reflects the reactions of competitors and potential entrants, which increase price elasticity. ${ }^{265}$

The application of demand-based pricing yields the familiar inverse elasticity rule for all services:

$$
\left(P_{i}-M C_{i}\right) / P_{i}=K / \eta_{i}
$$

where $i=1,2,3,4,5$ is an index representing the five classes of postal services. The other terms are defined as follows:

$$
\begin{aligned}
& P_{i}=\text { price of service } i \\
& M C_{i}=\text { marginal (attributable) cost of service } i \\
& K \quad=\text { a constant reflecting the shadow price of the break-even } \\
& \quad \text { constraint, } \\
& \eta_{i} \quad=\text { the price elasticity of demand for service } i
\end{aligned}
$$

The ratio of relative markups for any two services is governed therefore by the inverse ratio of elasticities of those two services, for any two services $i$ and $j$ :

$$
\frac{\frac{\left(P_{i}-M C_{i}\right)}{P_{i}}}{\frac{\left(P_{j}-M C_{j}\right)}{P_{j}}}=\frac{\eta_{j}}{\eta_{j}} .
$$

The elasticity of demand is defined as the percentage change in quantity demanded divided by the percentage change in price. Let $D_{i}\left(P_{i}\right)$ represent the demand function for service $i$, which depends on the price of service $i$. Then, the elasticity of demand is defined by:

$$
\frac{\delta D_{i}\left(P_{i}\right)}{\delta P_{i}} \frac{P_{i}}{D_{i}\left(P_{i}\right)}, \quad i=1,2,3,4,5
$$

The elasticity of demand is negative because a price increase lowers the quantity demanded.

The current approach to calculating elasticities of demand for postal services is based on estimates of the effect of a percentage change in postal rates on the percentage change in postal volume for a given class of mail. Professor George S. Tolley of the University of Chicago, whose testimony the Postal Rate Commission has relied upon in ratemaking proceedings, had used that method to estimate that the long-run elasticity of demand for first class

265. See William E. Landes \& Richard A. Posner, Market Power in Antitrust Cases, 94 HARV. L. REV. 937, 945 (1981). 
mail in the United States is $-.188 .{ }^{266}$ This general type of estimation provides a reasonably accurate description of the elasticity of the U.S. Postal Service's demand although it has engendered some disagreement about the econometric methodology used. ${ }^{267}$

The larger problem with the GAO's approach is that its estimates of the price elasticities of demand for the various classes of mail are contingent on the statutory barrier to entry that the Postal Service enjoys with respect to first class mail. The price elasticity for first class mail is consequently lower than it would be if there were no statutory monopoly. Professor William J. Baumol and the present author have written about this same problem in telecommunications regulation:

Application of Ramsey analysis to regulation is subject to [an] important caveat because feasibility of the calculations is likely to require them to take the pertinent demand elasticities as a given. In the language of economics, these elasticities are then treated as exogenous. But regulators considerably influence the firm's demand elasticity by their decisions and policies that affect the firm's actual or potential competitors. Clearly, severe constraint of firms' entry and pricing will somewhat immunize each enterprise from the competitive pressures of others. That immunity from competition will reduce the elasticity of each supplier's demand-that is, it will reduce the loss of business that results from a rise in its prices. The firm's price elasticity of demand thus must be said to be endogenously determined by the regulatory process itself. With such regulatorily influenced demand elasticities, it is not clear that Ramsey prices calculated ex ante will be those necessary for economic efficiency. ${ }^{268}$

When one applies that same reasoning to the U.S. Postal Service or Canada Post, it is clear that demand-based pricing simply reflects the statutory monopoly over letter mail and thus conveys little information about either the consumers' willingness to pay for postal services or the opportunity costs of alternative suppliers. Those elasticity estimates have precision without rigor.

That fallacy in postal ratemaking has not escaped notice in the past. Professor Leonard Waverman of the University of Toronto wrote in 1980 that the inverse elasticity rule "does not contemplate a firm that has one monopoly service and competes with other firms in its other services." ${ }^{269}$ He observed

266. Direct Testimony of George S. Tolley on Behalf of the United States Postal Service, Postal Rate and Fee Changes (Postal Rate Comm'n 1994) (No. R94-1).

267. GAO REPORT, supra note 237 , at $74-78$.

268. BAUMOL \& SIDAK, supra note 172, at 40-41 (footnote omitted).

269. Waverman, supra note 262 , at 20. 
that the true elasticity of demand for U.S. first class mail would result in its being assigned a much lower share of institutional costs:

The Postal Rate Commission has not dropped the inverse elasticity rule. Utilizing the words "competition" or "value of service," the commission sets rates above attributable costs in the same fashion as in the past: first-class mail bears the great percentage of institutional costs. Yet it is clearly first-class mail that faces the greatest potential competition. Electronic funds transfer may, within the decade, substantially lessen the number of first-class pieces carried by the Postal Service. The loss of traffic will destroy the elaborate house of cards on which the Postal Service and the commission have erected their rate structure. Without first-class mail to carry most of the common costs, rates will have to be increased for the other categories of mail. ${ }^{270}$

The U.S. Department of Justice similarly observed in 1977 :

First class mail users have the most inelastic demand; by eliminating competitive options through enforcement of the express statutes, this inelasticity of demand is maintained. Therefore, the lion's share of common costs is assigned to first class. ${ }^{271}$

Still other economists in the 1980 s debated in the academic literature the extent to which, given these "cooked up" elasticities, demand-based pricing rules are an unreliable way to determine the most efficient means of allocating joint and common costs across postal customers. ${ }^{272}$

The GAO also recognizes this problem, for it states that it has "assumed that First-Class Mail is the most inelastic class because it has stronger monopoly restrictions than the other classes of mail."273 Nonetheless, the GAO asserts-erroneously - that "the fact that elasticities may differ for different classes of mail because the law allows for different amounts of competition in those classes does not negate the validity of [the inverse

270. Id. at 24.

271. U.S. Dep't of Justice, Changing the PrIvate Express Laws: Competitive ALTERNATIVES AND THE U.S. POSTAL SER VICE 12 (1977).

272. See Frank A. Scott, Jr., The Pricing Policy of the Postal Service: Economics Misapplied, 4 J. Pol'y ANAlysis \& MGMT. 251 (1985); William B. Tye, The Postal Service: Economics Made Simplistic, 3 J. POL'y ANALYsIS \& MGMT. 62 (1983); William B. Tye, The Pricing Policy of the Postal Service: Policymaking Misunderstood, 4 J. POL'Y ANALYSIS \& MGMT. 256 (1985).

273. GAO REPORT, supra note 237, at 66. See also id. at 30-31 ("Because of historical experience and First-Class Mail protection from unrestricted competition by the Private Express Statutes, postal ratemaking experts believe that this service has a relatively inelastic demand-i.e., the demand for the service is not greatly affected by changes in postal rates."); id. at 64 ("[T] he relative inelasticity of First-Class Mail may be largely due to the legal monopoly granted to the Postal Service."). 
elasticity rule] for ratemaking in the Postal Service."274 Instead, the GAO argues that those elasticities should simply be taken as a given for pricing purposes "[g]iven the market structure within which the Postal Service must operate."275 The GAO makes that assertion despite its observation that the econometric estimates of demand elasticities omit a number of factors:

The omitted variables might include private competitors' prices, the quality of Postal Service products and services relative to those of its competitors' entrepreneurship, product and marketing innovations (e.g., advances in computers and telecommunications), and exogenous changes in market conditions and in consumers' tastes and needs. ${ }^{276}$

Even if additional variables were included, as the GAO implies that they should be, the estimation of demand elasticities still would fail to give an accurate representation of competitor responses in the absence of the regulatory barriers to entry enjoyed by the Postal Service.

\section{The Correct Demand Elasticity for Computing Ramsey Prices for the U.S. Postal Service}

When we correctly assume that the artificially induced firm price elasticity of demand for the U.S. Postal Service does not equal the actual market price elasticity of demand, we can immediately see the fallacy of the GAO's analysis concerning the suitability of the inverse elasticity rule. To illustrate this point, suppose that entry were permitted into first class mail and that the new entrants' actions could be described by a supply function $S\left(P_{1}\right)$ that depended on the U.S. Postal Service's price for the service, $P_{l}$. Then the Postal Service's residual demand for the service would equal the difference between the market demand $D\left(P_{l}\right)$ and the supply response of competitive firms:

$$
D_{l}\left(P_{l}\right)=D\left(P_{l}\right)-S\left(P_{l}\right)
$$

Therefore, the price elasticity of demand for the Postal Service for first class mail $\eta_{l}$ can be expressed in terms of the entire market's price elasticity of demand $\eta$, the Postal Service's market share $s$, and the (positive) price elasticity of supply of the other firms on the competitive fringe of the market $\eta^{\mathrm{s}} \cdot{ }^{277}$ That is,

274. Id.

275. $I d$.

276. Id, at 74 .

277. The elasticity of supply is $\eta^{3}=\left(\delta S\left(P_{l}\right) / \delta P_{l}\right)\left(P_{l} / S\left(P_{l}\right)\right)$, which is positive because the supply function is increasing in the price. The market share of the Postal Service is $s=D_{l}\left(P_{l}\right) / D\left(P_{l}\right)$. 


$$
\eta_{1}=\frac{\eta}{s}-\frac{\eta^{s}(1-s)}{s}
$$

By statute, $s$ must equal one because the supply of competing firms is held at zero. In general, competition affects the elasticity of the firm's demand in a more complicated manner-that is, it cannot simply be subtracted. A complete analysis would need to take into account the costs of entry and operation for competitors. In any case, competition will increase the Postal Service's elasticity of demand, as it has clearly done in parcel post and express mail.

In other words, the Private Express Statutes require that the Postal Service have all the market for the delivery of first class mail. That requirement causes the second term in the numerator to become zero-which prematurely ends any inquiry by the GAO into the extent to which a fringe of competing suppliers would enter the delivery of first class mail if allowed to do so. The price elasticity of demand for first class mail is artificially low because the Private Express Statutes forbid competition and thus arbitrarily drive down to zero the price elasticity of fringe supply (which affects the relevant price elasticity of demand). The low elasticity of demand that the GAO asserts to exist for first class mail is then seen to be a regulatory contrivance-one preordained by the Postal Service's historical resistance to allowing competitive entry into first class mail through relaxation or repeal of the Private Express Statutes.

Another way to understand the elasticity of demand for first class mail is to consider the effects of having a substitute service. The products of the U.S. Postal Service are differentiated from those of private carriers in terms of brand name, pickup locations, service quality, and other features. Suppose that there is a competitive substitute for first class mail. Let $D\left(P_{1}, P_{S}\right)$ represent the demand for the Postal Service's first class mail, evaluated at the price of first class service, $P_{I}$ and the price of the competitive substitute, $P_{S}$. The own-price elasticity demand for first class mail is

$$
\eta_{l}\left(P_{l}, P_{s}\right)=\frac{\delta D\left(P_{l}, P_{s}\right)}{\delta P_{l}} \frac{P_{l}}{D\left(P_{l}, P_{s}\right)}
$$

The entry barriers established by the Private Express Statutes can be modeled as a very high price for the competitive substitute. Under reasonable conditions, a higher price for the substitute will lower the elasticity of demand for first class mail. ${ }^{278}$ Therefore, legal and regulatory restrictions on substi-

278. The effect of the price of the substitute on the elasticity of demand is: $\delta n\left(P_{1}, P_{\mathrm{S}}\right) / \delta P_{\mathrm{S}}=\left[P_{1} /\left(D\left(P_{1}, P_{\mathrm{S}}\right)\right)^{2}\right] \times\left[D\left(P_{1}, P_{\mathrm{S}}\right) D_{12}\left(P_{1}, P_{\mathrm{S}}\right)-D_{1}\left(P_{1}, P_{\mathrm{S}}\right) D_{2}\left(P_{1}, P_{\mathrm{S}}\right)\right]$. 
tutes for first class mail have the effect of artificially reducing the elasticity of demand for first class mail.

Although the GAO report acknowledges that the statutory monopoly over the delivery of first class mail lowers the price elasticity of demand for such mail, ${ }^{279}$ the GAO nonetheless fails to recognize that this critical fact invalidates the reasoning by which the GAO reaches its conclusion that the inverse elasticity rule should govern the allocation of institutional costs to the various classes of mail. We have no reason to suppose (as the GAO evidently does) that pricing according to the inverse elasticity rule would maximize consumer welfare when the Postal Service's price elasticity of demand for first class mail is an artifact of legal barriers to entry.

A. Michael Spence, a respected economist who is the current dean of Stanford Business School, argued in 1983 that the distorting effect of the Private Express Statutes on the price elasticity of demand for first class mail does not by itself imply that first class rates derived from the inverse elasticity rule are excessive:

It is certainly true that if the private express statutes were dropped, the elasticity of demand for USPS services would rise in first class mail, and that would tend to reduce those rates as they emerge from optimal pricing formulas. But the conclusion that the first class mail rates were artificially high does not follow. The issue is whether it is a good thing or not to expose USPS to competition. That issue is not decided by describing correctly one of the consequences of allowing competition. Therefore, without prejudging the whole issue, to repeal the private express statutes on the ground that they artificially create a demand facing the Postal Service for first class mail that is inelastic, would be to do it for the wrong, or at least an insufficient reason. ${ }^{280}$

Spence raises a.valid point, but it is not one that detracts from the conclusion that the GAO's proposal for inverse elasticity pricing by the Postal Service is analytically flawed. That same conclusion would apply to Canada Post.

As shown in Part II, one cannot credibly conclude that Canada Post is a natural monopoly. Competition is therefore an available option if Parliament should conclude, in response to the question that Spence poses, that it is desirable to expose Canada Post to competition. The analysis in Part III

Because the two products are substitutes, a higher price for the substitute would increase demand for first class mail, $D_{2}\left(P_{1}, P_{\mathrm{S}}\right)>0$. If the cross-price effect is either positive or not too small, $D_{12}\left(P_{1}, P_{\mathrm{S}}\right)$ $\left[D_{1}\left(P_{1}, P_{\mathrm{S}}\right) D_{2}\left(P_{1}, P_{\mathrm{S}}\right) / D\left(P_{1}, P_{\mathrm{S}}\right)\right]$, then the demand for first class mail becomes less elastic as the price of the substitute rises.

279. GAO REPORT, supra note 237, at 62-63.

280. A. Michael Spence, Regulating the Structural Environment of the Postal Service, in THE FUTURE OF THE POSTAL SERVICE, supra note 160, at 197, 206-07 (emphasis in original). 
showed that a government-owned postal monopoly has no advantage over competition in the provision of postal services. In short, the Private Express Statutes and Canada Post's mandate to maintain "basic customary postal service" directly harm consumer welfare, especially since the alternative of competition is readily available in each case. ${ }^{281}$ That is not to say that repeal of the Private Express Statutes-or Canada Post's mandate-is justified simply because such statutory prohibition on entry has the secondary effect of distorting Ramsey pricing principles when applied to the Postal Service in the simplistic manner advocated by the GAO. In short, the foregoing analysis provides a sufficient reason not only to reject the recommendations of the GAO's 1992 report, but also to repeal the Private Express Statutes.

\section{The U.S. Postal Service's Pursuit of "Profit"}

Since regulators first addressed Ramsey pricing in ratemaking proceedings several decades ago, the concept has invited the recurrent but uninformed criticism that it is tantamount to a rule allowing the supposedly regulated monopolist to charge whatever the traffic will bear. ${ }^{282}$ That criticism is incorrect because it ignores that Ramsey prices are constrained to yield profits no higher than the competitive earnings level, while the profits of a price-discriminating monopolist are unconstrained. Prices that are set subject to a profit constraint will be considerably lower than those adopted in the absence of such a constraint. ${ }^{283}$

The irony of the GAO's 1992 report on postal pricing, and of the U.S. Postmaster General's 1995 call for greater pricing flexibility, is that they are in essence recommendations for the U.S. Postal Service to approximate not Ramsey pricing but rather unconstrained price discrimination by a firm having a guaranteed monopoly in one market and facing competition in its other markets. The Postal Service has demonstrated a proclivity to characterize, through incorrect measurement or misallocation, an inordinate share of its total costs as institutional costs. The GAO would then place a greater share of those inflated institutional costs on customers of first class mail-according to its specious interpretation of the inverse elasticity rule, which fails to adjust for the fact that the price elasticity of demand for first class mail is artificially low because the statutory monopoly on the delivery of first class mail excludes any possibility of competitive entry.

In short, the economic essence of what the GAO and the U.S. Postmaster General advocate is that the U.S. Postal Service should be allowed to charge first class customers whatever the traffic will bear and charge other customers

281. Canada Post Corporation Act, R.S.C., ch. C-10, \$ 5 (1985) (Can.).

282. See BAUMOL \& SIDAK, supra note 172, at $52-53$ \& n.2 (citing American Tel. \& Tel. Co. 64 F.C.C.2d 131, FII 1121-24 at 469-70 (1976)).

283. Id. 
of other classes of mail prices that undercut private competitors. Thus, unrestricted pricing combined with statutory monopoly will yield monopoly profits for the Postal Service. Expansion into competitive markets will yield additional profits if there are economies of scope between the provision of first and third class mail and the provision of expanded services such as parcel post and express mail. If such expansion is subsidized, however, the expansion creates economic inefficiencies. Such a set of outcomes would comport with the Postmaster General's prediction that, if the Postal Service were granted greater pricing flexibility and freedom to enter new markets, the enterprise "could become a profit center for the federal government." 284 Despite Canada Post's recent losses, its chief executive officer has similarly asserted that the corporation's mandate is "to earn a return that is commensurate with that earned by firms of similar size, facing similar risks. . . 10-12\%."285

In what sense will the U.S. Postal Service earn such "profits"? The Postal Service typically runs losses that accrue as institutional costs to be recovered in the future through postal revenues. ${ }^{286}$ In May 1995 the postmaster general stated: "We are going to pay down billions of dollars in prior year deficits and debt, and put the Postal Service on solid financial footing." 287 That recovery of prior years' losses represents another way in which attributable costs are mischaracterized as institutional costs: some portion of last year's unrecovered attributable costs return in the current year as institutional costs because of the Postal Service's determination to recover prior years' losses. If the Postal Service earns revenues in excess of costs, those returns will presumably accumulate as a surplus. As noted previously, the Postal Service-unlike Canada Post-pays no dividends. Continuation of cost-ofservice postal ratemaking means that positive net earnings at best will serve to delay rate increases. The Postal Service has an incentive to absorb this "free cash flow" by increasing expenditures or investing in future expansion of postal services. $^{288}$

Unlike privately owned companies, the U.S. Postal Service has no market test for those investment decisions. Competitive firms must take into account the cost of capital in their investment decisions. The Postal Service is relatively immune from such considerations. Were it not for the fact that the Postal Service is losing money, it would be difficult for those reasons to

284. Marvin Runyon, U.S. Postmaster General, Address to the National Press Club, Washington, D.C., Jan. 31, 1995, available in LEXIS, News Library, Fednew File.

285. Clermont Testimony, supra note 52, at 4.

286. Opinion and Recommended Decision, Postal Rate and Fee Changes, at II-16 to II-24 (Postal Rate Comm'n 1994) (No. R94-1).

287. Postmaster General Marvin Runyon, Address at the National Postal Forum, Nashville, Tennessee 2 (May 8, 1995) (on file with author).

288. See Michael C. Jensen, Agency Costs of Free Cash Flow, Corporate Finance, and Takeovers, 76 AM. ECON. REV. PAPERS \& PROC. 323 (1986); MILGROM \& ROBERTS, supra note 192, at 492-94. 
evaluate the extent to which it was generating profits. Moreover, the Postal Service's reporting requirements differ substantially from those of publicly traded companies. Since the Postal Service employs accounting methods that diverge from those used by private firms and is highly secretive about its costs, it would be difficult to compare its profits with the accounting profits of private companies.

\section{E. Implications}

The postal ratemaking process has unusual cost allocation and accounting procedures that bear little relationship to economic theory. Conventional regulatory safeguards to prevent cost misallocation are absent from postal rate regulation. The statutory monopoly over letter mail conferred on Canada Post by the Canada Post Corporation Act intentionally suppresses competition and consumer choice. In the United States, the Postal Service's understanding of Ramsey pricing principles is faulty. In considering Canada Post's mandate, the Canadian government should avoid the GAO's erroneous interpretation of those principles.

When factors relating to statutory monopoly are considered in the postal ratemaking process, it becomes clear that reliance on inverse elasticity pricing could maximize consumer welfare only by sheer accident. It is far more likely that postal rates set in such a manner would harm consumer welfare and competitive markets for postal services. It would be a mistake to employ inverse elasticity pricing until postal regulation has been dramatically reformed, or until Canada Post has been commercialized and its statutory monopoly repealed.

\section{Policy Recommendations}

The foregoing analysis implies that Parliament will be forced to consider four alternatives for the future of Canada Post: acquiesce, privatize, commercialize, or strengthen public oversight. Of those four, commercialization may be most attractive in terms of being a politically feasible option that would appreciably enhance economic welfare.

\section{A. Acquiescence}

The preceding discussion of Canada Post's privileges, performance, and objectives explains why it is inadvisable on public policy grounds for Parliament to allow Canada Post to continue its expansion in competitive markets that are ably served by private firms. Continued expansion by Canada Post threatens not only the well-established delivery markets such as parcel post, express mail, newspapers, and commercial mailing services, but 
also emerging communications markets such as on-line services and electronic commerce. Expansion into robust private markets without such counterbalancing constraints as private ownership or competition in the delivery of letters is unlikely to enhance consumer welfare.

The competitive Canadian postal markets do not need a governmentowned participant with a monopoly business. Many carriers serve the Canadian express mail market, including Federal Express Canada, United Parcel Service, Loomis Courier, Canpar Transport, and Purolator (as it did even before Canada Post bought a majority interest). The market for parcel delivery is served by numerous companies, including Consolidated Freightways, Inc., DHL Worldwide Express, United Parcel Service, Roadway Services, and Pittston.

The more Canada Post is permitted to expand in, and into, competitive markets, the more such acquiescence will increase both the incentive and the opportunity for Canada Post to engage in anticompetitive cross-subsidization of its provision of competitive services.

Part IV shows that given the opportunity, a company could achieve such anticompetitive results in two steps. First, it could continue to distort and misallocate the attributable costs of providing competitive service by characterizing those costs instead as institutional costs that should be spread across all categories of its enterprise according to Ramsey pricing principles. Second, it could distort the inverse elasticity rule, which follows from Ramsey pricing analysis, and thus would overstate the proportions of the institutional costs that should be allocated to the monopoly business. That overallocation of institutional costs to the monopoly business occurs and will continue to occur because the price elasticity of demand estimated by the privileged entity for the monopoly business fails to consider the fact that a statutory barrier to entry artificially prevents competitive firms from entering the market under any circumstances, even when the company sets a price for that service far in excess of marginal cost. Although Canada Post is not explicitly rate-regulated, it still has these incentives while preparing its budgets. In the United States, the Postal Service's inference of price inelastic demand for first class mail is the direct consequence of the monopoly that such public enterprise enjoys.

For those reasons, one must conclude that on grounds of economic welfare the least attractive choice that one could make concerning Canada Post would be to acquiesce to the continued expansion of the enterprise into commercial markets.

In its report the Review concurs with this position. It views Canada Post's "aggressive" entry into competitive markets as creating the "serious anomaly [of] an unregulated public sector monopoly engag[ing] in unrestrained competition with the private sector." 289 It further observes that the anomaly was "intensified" by yet another anomaly: that of a "corporation carry[ing]

289. MANDATE REVIEW, supra note 2, at 20. 
out its competitive activities on the basis of cost-accounting processes that [were] neither publicly open, transparent, reliable nor in any possible way confidence-inspiring." 290

Thus, the Review recommends that Canada Post withdraw from competing with the private sector in areas outside its core postal service mandate. It defines the core postal services as being those that "the private sector could not provide as well in accordance with the principles of universal service and uniform pricing . . . "291 According to the Review, the provision of such core services constitutes "the public policy reason for the corporation's existence." 292 Specifically, the Review seeks the withdrawal of the corporation from the courier business, unaddressed admail, the operation of business support or mailing centers, electronic products and services, and non-postal merchandise retailing.

The Review finds that Canada Post is an unfair competitor in the unaddressed admail and courier services and as such has a detrimental impact upon the private firms in those markets. The Review reasons that "the corporation's misallocation of costs constitutes a form of cross-subsidization, whether intentional or otherwise" and that Canada Post's exploitation of a publicly funded network is "seriously unfair" because it artificially gives the corporation "a pricing advantage over [its] competitors."

The Review recommends the divestiture of Purolator but distinguishes expedited mail as a service that the corporation can continue to provide. The Review reasons: "Disallowing Canada Post from providing pick-up service [alone would] remove it from direct competition with courier companies, without significantly affecting its ability to exploit cost economies of scale and scope within its existing lettermail network."294 In addition, the Review recommends that Canada Post withdraw from the provision of unaddressed admail services. The Review reasons that such services do not "fall within Canada Post's public policy responsibilities."295 Nonetheless, the Review does exempt the provision of such services to governments and their elected members by Canada Post. ${ }^{296}$

Electronic products and services were also included in the list of activities from which the Review seeks Canada Post's removal. But the Review qualifies its recommendation, stating that "in the event that the corporation identifies any electronic product or service that meets a demonstrable public policy need and that the private sector is unable or unwilling to provide in a way that would adequately serve the public interest,

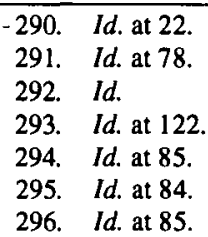


Canada Post should be able to apply to the government for permission to provide that specific product or service."297 The Review identifies the problem with the corporation's participation in the electronic services market as its expenditure of resources in an area in which it has no special expertise or advantage. ${ }^{298}$

The Review cites to four overarching reasons for its recommendation that Canada Post withdraw from those competitive markets. First, it states that Canada Post's participation in those markets in competition with private firms placed the Canadian government in "an untenable position with regard to fair treatment of the private sector."299 The Review adds that "[f]or understandable reasons related to past behaviour, secretiveness and lack of accountability, there is ... no scenario under which private companies [would] believe that Canada Post is a fair competitor." ${ }^{300}$ Second, the Review observes that Canada Post's participation in competitive markets distracts it "from concentrating on the pursuit of excellence in the provision of core postal services, and distorts] its corporate culture by whipsawing it between public service and purely commercial orientation." 301 Third, it reasoned that the corporation's presence in competitive markets was "unnecessary in view of the private sector's now-developed capacity to provide the same services, and therefore they [were deemed] inconsistent with the Government's determination only to be involved in those activities for which there [was] a public policy reason. ${ }^{302}$ Finally, the Review stated that such participation was "non-essential from a financial point of view, because other options exist[ed] to maintain an adequate revenue base for the corporation without the problems that its involvement in competitive activities engender[ed]." ${ }^{303}$

\section{B. Privatization}

Privatization is the opposite pole on the spectrum of policy options available to Parliament. If Parliament privatized Canada Post and removed its exclusive privilege over letter mail, the problems of potential anticompetitive cross-subsidization would eventually disappear. Canada Post's reservoir of monopoly rents earned from letter mail would dry up and would thus deny the firm the ability to cross-subsidize competitive services. Privatization would force Canada Post to maximize profits rather than employment or some other

\footnotetext{
297. Id. at 86 .

298. Id.

299. Id. at 79 .

300. Id.

301. Id.

302. Id.

303. Id.
} 
objective, and competition would force this multiproduct firm to adopt subsidy-free prices for its various services. ${ }^{304}$

The Review is not convinced that a privatized Canada Post, without exclusive privilege over lettermail, "would be an improvement on keeping postal service in the public sector." 305 It reasons that both a regulatory agency and subsidies still would be required for the provision of postal services so that remote and sparsely populated regions would be serviced by the private postal entity. ${ }^{306}$ It adds that a regulatory regime would be required to coordinate the provision of postal services because the Review envisages a fragmented postal system resulting from the removal of the exclusive privilege. ${ }^{307}$ According to the Review, the resultant fragmentation would be caused by the privatized corporation focusing its competitive efforts in the high-density urban areas to the exclusion of the rural and remote regions. ${ }^{308}$

The Review cites the decisions of Britain, Australia, and New Zealand, which it calls "countries with exceptional enthusiasm for privatization" not to privatize their postal services and the fact that very few Canadian companies have expressed enthusiasm for a privatized Canada Post as support for its position. ${ }^{309}$ In addition, the Review expresses its concern that the transition from a public to a private postal system would be marked by a protracted period of disruptions requiring substantial adjustments over several years. It believes that this disruption, in turn, would harm Canadian business. ${ }^{310}$

\section{Commercialization}

A public enterprise can be commercialized even if it is never privatized. The legal and economic analysis in the preceding sections suggests that a plan for the commercialization of Canada Post should include at least the removal of statutory entry barriers and other privileges, and relief from incumbent burdens.

\section{Remove Canada Post's "Exclusive Privilege" and Any Other Explicit or Implicit Privileges of Public Ownership}

Parliament should remove Canada Post's exclusive privilege over letter mail. The general rule in the Canadian economy is that attempted monopolization is a crime, but when it comes to delivering letters, it is attempted

304. For a thoughtful discussion of the practical business steps that would be required to privatize the U.S. Postal Service, see Bert Ely, Privatizing the Postal Service: Why Do It; How to Do It, in FreE THE MAIL: ENDING THE POSTAL MONOPOLY 117 (Peter Ferrara ed., 1990).

305. MANDATE REVIEW, supra note 2 , at 75.

306. Id. at 74.

307. Id.

308. Id.

309. Id. at 75 .

310. Id. 
competition that is the crime. If Canada Post wishes to compete on the merits with private firms, it should not be allowed to do so behind the protection of a statutory monopoly.

Parliament also should eliminate Canada Post's exclusive access to customers' mailboxes, wherever it exists. Parliament should mandate that bonded entrants into postal service markets receive equal access to Canada Post's increasing number of cluster mailboxes. Furthermore, Parliament should mandate that bonded private firms receive equal access to mailboxes in apartment buildings. Greater access would increase competition across various existing and future classes of mail by lowering entry costs for competitors and lowering the consumer's cost of switching from Canada Post to another firm. Eliminating that small but widespread entry barrier would facilitate competitive services and increase customer convenience.

More generally, Parliament should specify by statute that, for as long as Canada Post remains publicly owned, it shall be subject to all laws generally applicable to private firms and shall have no special privileges or immunities arising from its public ownership. Canada Post should not be permitted to benefit from its government-owned status in terms of tax privileges, reduced costs of borrowing, minimal accountability to shareholders, and a government-funded pension plan.

In addressing the issue of exclusive privilege, the Review states that it was the price the Canadians had to "pay for maintaining universal postal service at affordable rates." 311 The Review adds that the privilege "exists by the will of Parliament on behalf of the people of Canada." 312 The Review notes that only three countries had abolished similar privileges and that most others subscribed to the position that universal postal service with uniform rates would not be possible without such exclusive privilege. As for Canada, the Review observes that if the privilege was removed, "private companies would concentrate on competing in high-density urban areas ... and ignore rural and remote markets." 313 It explains that because of great distances, sparse populations, low mail volumes, and numerous distribution points rural Canada "offer[ed] little prospect of profitability." 314 The Review reasons that "[b]ecause Canada Post's postage rate must blend the cost and revenue requirements of serving both urban and rural areas, and handling both local and forward mail, private firms serving only the most lucrative urban markets would be able to undercut the corporation's rate in those markets and siphon away business." 315 The Review argues that Canada Post would then find itself still having to service its extensive network in order to provide universal service with both lower volumes and revenues. The eventual result, the

311. Id. at 70 .

312. Id,

313. Id. at 69.

314. Id.

315. Id. 
Review concludes "would be dramatically higher postage rates, an end to universal service or, most likely, some combination of both. Even worse, [Canadian] postal system would be irrevocably fragmented." 316

To preserve universal service without the grant of an exclusive privilege to Canada Post, the Review foresees the need for "some form of subsidy scheme to permit a financially-weakened Canada Post to continue to serve non-urban areas or to induce private companies to serve them instead." 317 In addition, the Review envisages the need for a regulatory agency with a mandate of "ensur[ing] that an increasingly fragmented postal system did not descend into chaos." 318

\section{Relieve Canada Post of Its Universal Service Obligation and Other Incumbent Burdens}

If Canada Post is to be stripped of its unique statutory privileges as a condition of being allowed to compete freely against private firms, it should also be relieved of its unique statutory obligations. The most conspicuous of those obligations is the universal provision of mail delivery.

There is a powerful efficiency-based argument for removing the incumbent burdens of Canada Post, an argument distinct from concerns about symmetry or fairness. As a matter of political economy, it would be easier to remove Canada Post's exclusive privilege and other barriers to competition in postal services if Parliament were simultaneously to remove the putative justification for those special privileges. Because universal service is the most prominent of Canada Post's incumbent burdens, it is also Canada Post's strongest justification for the maintenance of its exclusive privilege and the continuation of its expansion into competitive markets.

From the perspective of maximizing consumer welfare, it would be regrettable if the commitment to providing mail service to rural and other high-cost segments of the population were to have the effect of denying all segments of the population the substantial benefits that would flow from having multiple providers of letter mail service rather than only one provider. There is also a jurisprudential argument against funding universal service or other incumbent burdens through the creation of artificial monopolies. The cross-subsidies built into uniform postal rates are an implicit regime of taxes and appropriations. Taxing and spending is properly the role of Parliament. The magnitude of the subsidy to rural recipients of mail should be apparent from an explicit line item in the budget; it should not be an amount that can be inferred only by undertaking extensive economic analysis of the crosssubsidies effected by the monopoly over letter mail.

$\begin{array}{ll}316 . & I d . \\ 317 . & I d \\ 318 . & I d .\end{array}$


Despite the repeated efforts of scholars to convey those messages in a variety of regulated industries, including postal delivery, rate structures containing cross-subsidies have endured in such industries. If one hopes to influence public policy in the real world, it is therefore necessary to take account of how actual political constituencies and institutions may prevent the achievement of reforms that would increase economic welfare. By enacting legislation to fund universal postal service in a way that does not depend on the artificial creation of a monopoly, Parliament would deny opponents of postal commercialization their most politically effective argument for retaining Canada Post's exclusive privilege over letter mail and other special privileges.

There are at least two general means by which Parliament could decouple universal service from the postal monopoly. First, Parliament could send postal subsidies directly to consumers in rural areas. Those subsidies could even be means-tested, if one's low income were considered to be more important than one's rural address. Those customers would then be billed directly by the carrier of last resort for the high cost of what might be called "terminating access," to borrow a telecommunications concept. The lower basic stamp price that would result would not include the surcharge for delivery to costly, remote areas. A second means would be for the government to solicit bids from private firms to deliver mail to remote areas for a specified contract term. The winning bid would be that which proposed to provide service at the lowest subsidy from the government. If Parliament were to adopt either approach, it could end the false rhetoric that Canadian consumers must tolerate a monopoly to have universal service.

The Review identifies postal service to be "a vital public good and a key element of [Canadian] communications infrastructure" and as such "it should be universally available." ${ }^{, 319}$ The Review cites to the fact that some $95 \%$ of the Canadian population still sent letters, cards, and bills through the mail. ${ }^{320}$ It rejects the economic inefficiency argument against both universality and uniformity of rates as not being a "sufficient criterion for sound public policy." ${ }^{321}$ The Review agrees with Canada Post's position that its central public policy function was to continue providing affordable universal lettermail service at uniform rates. The Review goes even further and recommends that ". . . providing universality of service and uniformity of price for lettermail be regarded as integral elements of the mandate of Canada Post Corporation [and that] in any future amendments to the Canada Post Corporation Act, the obligation to provide universal service at a uniform rate for lettermail be explicitly included as part of the corporation's mandate."322

319. Id. at 67.

320. Id.

321. Id.

322. Id. at 68 . 


\section{Stricter Public Oversight}

If commercialization of Canada Post is not politically feasible along the lines just described, then Parliament must select the remaining option of substantially increasing public oversight of Canada Post. That option contains three necessary elements. One is to create an independent body to regulate Canada Post's rate-setting procedures. The second is to eliminate from Canada Post's objectives the goal of generating profits for the federal government. The third is to limit strictly the lines of business in which Canada Post may operate.

\section{Establish a Regulatory Oversight Commission}

If Canada Post remains a government-owned corporation with a statutory monopoly over letter mail, then Parliament should create a regulatory commission with full powers to set rates, to order public disclosure of Canada Post's costing methodologies, and to prescribe modification of those methodologies as needed. In other words, Parliament should establish a stricter watchdog to ensure that cross-subsidization of competitive businesses with monopoly rents never occurs. That regulator must have the power to order whatever structural relief (such as divestiture of operating units, separate subsidiaries, accounting separations, and so forth) it deems necessary to regulate Canada Post in a manner that advances the purposes of public provision of postal services.

The Review opines that oversight of Canada Post by yet another regulatory agency creates more difficulty than value. First, it reasoned that the corporation was "vehemently opposed to third-party regulation." 323 The Review cites to a statement made at the Review's public meeting in Ottawa by the President of the corporation, Mr. Clermont, where he said in part: "What they want is an American system, one that will tie our hands in such a way that it will give them free reign to capture our markets or at least the ones that are lucrative and destroy the only Canadian competitor large enough to compete effectively all across our nation." 324

Second, in light of Canada Post's opposition, the Review observes that establishing a new regulatory regime to oversee the postal service would have the net "effect of adding new controversies and pressures to those already existing in the regulatory field." 325 It explains that because decisions of regulatory bodies are routinely appealed to the Cabinet, rulings of a postal service regulatory agency will, most likely, suffer the same fate. Such appeals,

\footnotetext{
323. Id. at 71 .

324. Id. at 71-72.

325. Id. at 72 .
} 
the Review finds, would be even more probable in the case of the postal regulatory agency, "since the corporation would be certain to invoke 'commercial sensitivity' in insisting that detailed data on which the rulings were based not be made public.,326

Third, the Review reasons that a regulatory agency could exasperate an already complicated relationship between the government and the corporation. It argues that "[t]he Government's rights to direct the corporation as its shareholder and owner could easily come into conflict with the need to maintain an arm's-length approach toward matters subject to regulation."327

Finally, the Review, pointing to the U.S. experience, suggests that "the regulatory process is by its nature time-consuming and costly." 328 In support of that proposition the Review quotes from the Canadian Competition Bureau's submission to it, in which the Bureau stated that "[t]he processes of the U.S. Postal Rate Commission have been judged as expensive, bureaucratic, inefficient and wasteful."329

\section{Clarify That It Is Not Canada Post's Mission to Be a "Profit Center" for the Federal Government}

If Canada Post is not commercialized, Parliament should ensure that Canada Post will not attempt to generate profits for the federal government by displacing the business of efficient rivals in competitive markets. This recommendation may run counter to Canada Post's possible plan to issue shares to its employees; but such a plan is itself an endorsement for privatization. In other words, if the beneficial incentive effects of employee ownership are a large concern, then the better course of action is to distribute some or all shares to the employees and make the securities immediately marketable to third parties, thereby privatizing Canada Post.

The economic justification for public enterprise is either that there is a natural monopoly or that there is an uncompensated or untaxed externality. Neither is present in the case of postal services, or at least not present in sufficient magnitude to necessitate public ownership as the appropriate form of government intervention. Economic theory does not justify public enterprise on the ground that the government can make a profit competing against private firms. The government's source of funds is better confined to its use of the more politically transparent means of taxing the private economic activity of firms and households.

One of the Review's recommendations is that Canada Post "concentrate on excellence in its core lettermail responsibilities as long as they are relevant,

326. Id.

327. Id. at 73 .

328. Id.

329. Id. 
and be treated as a sunset industry and phased out if the time ever comes when they are no longer relevant." ${ }^{330}$ In reaching that conclusion, the Review rejects two key premises on which Canada Post's defense of its participation in the competitive markets rested. In its submission to the Review, the corporation thus articulated its first premise: "[T]he scale and scope of the distribution network required for universal letter services in turn requires that [Canada Post] also provide competitive services that generate contributions in excess of their incremental costs and thus defray overhead and other fixed costs of the network." 331 In the same submission the second premise was stated as follows: "As lettermail business is lost to courier, electronic and other alternatives, [Canada Post] can best protect itself by supplying competitive services that meet market needs." 332 The Review finds "Canada Post's strategic vision of expanding into competitive activities to supplement revenues and to protect itself against anticipated lettermail volume declines is imperfect in practice and in principle.",333

The Review observes that Canada Post's emphasis on competitive activities has not yielded "sufficient revenues to allow the corporation to consistently achieve break-even status." 334 Thus, the Review concludes that the corporation's strategy of defraying fixed costs of its network through its entry in competitive markets had worked poorly. ${ }^{335}$ Moreover, the Review notes that the corporation's aggressive expansion in competitive markets as an unregulated public monopoly has made it an unfair competitor vis-a-vis private firms. The Review identifies as "perhaps [the] most fundamental shortcoming" of Canada Post's entry into competitive markets its shortchanging the core public policy responsibilities that constitute the reason for its existence. ${ }^{336}$ The Review states that "[t]he corporation exists, ultimately, to deliver the mail, and yet its most visible preoccupations in recent years has been with the establishment and expansion of various competitive activities.",337

\section{Remove Canada Post from Markets That Are Demonstrably Competitive}

In any market where private firms already provide adequate mail or communication services, there is no need for Canada Post. Parliament should clarify Canada Post's mandate to remove the firm by statute from any such

330. Id. at 61 .

331. Id. at 58.

332. Id. at 60 .

333. Id. at 61 .

334. Id. at 58 .

335. Id.

336. Id. at 59.

337. Id. 
market, or Parliament should delegate such removal power to the proposed regulator. Where markets are satisfying consumer demand through the competitive provision of postal services, no market failure is present that could justify government intervention, let alone intervention in the extreme form of a publicly owned enterprise. The antitrust laws are sufficient to ensure that postal markets that are demonstrably competitive today will not be monopolized or cartelized by private firms when Canada Post exits the field.

\section{Conclusion}

The path to more competitive and innovative mail service in Canada does not involve facilitating predatory cross-subsidization by a government-owned monopolist. In other words, the proper policy is not one of Parliamentary acquiescence to the unconstrained diversification and corporate aggrandizement of Canada Post. At the other extreme, privatization is efficient on economic grounds but may be politically unfeasible.

Given those considerations, the policy most conducive to greater economic welfare is likely to be the commercialization of Canada Post. Such a reform package would remove the exclusive privilege over letter mail and other statutory privileges enjoyed by Canada Post; it would also relieve Canada Post of its incumbent burdens. This set of reforms might eventually lead to the privatization of Canada Post although it need not. Indeed, privatization would be unconscionable on economic grounds if it failed to provide for removal of Canada Post's exclusive privilege.

In the words of Canada Post's chief executive officer, given a level playing field, "let the market place decide who should be in the game and who is best." ${ }^{338}$ Parliament should indeed level the playing field, which means removing all of Canada Post's unique privileges and burdens. If, on the other hand, Parliament declines to commercialize Canada Post, the government's remaining option will be considerably more invasive. Canada Post's continued enjoyment of statutory privileges will necessitate much greater oversight of the enterprise by a new postal regulator. It will be necessary for Canada Post to divest operations in demonstrably competitive lines of business, and for federal enforcement authorities to engage in closer antitrust oversight to ensure that Canada Post does not abuse its lawful monopoly over letter mail. The least acceptable course of action is for Parliament to continue to do nothing in the face of Canada Post's expanding empire.

338. Clermont Testimony, supra note 52 